SAULO MISSIAGGIA VELASCO

SIMETRIA E TRANSITIVIDADE EM DISCRIMINAÇÕES CONDICIONAIS DE HUMANOS E POMBOS (COLUMBA LIVIA) AVALIADAS SOB CONDIÇÕES DE REFORÇAMENTO DIFERENCIAL

SÃO PAULO

2009 


\author{
UNIVERSIDADE DE SÃO PAULO \\ INSTITUDO DE PSICOLOGIA \\ DEPARTAMENTO DE PSICOLOGIA EXPERIMENTAL
}

\title{
SIMETRIA E TRANSITIVIDADE EM DISCRIMINAÇÕES CONDICIONAIS DE HUMANOS E POMBOS (COLUMBA LIVIA) AVALIADAS SOB CONDIÇÕES DE REFORÇAMENTO DIFERENCIAL
}

SAULO MISSIAGGIA VELASCO

Tese apresentado ao instituto de Psicologia da Universidade de São Paulo, como parte dos requisitos para obtenção do título de Doutor em Psicologia

Área de concentração: Psicologia Experimental

Orientador: Prof. Dr. Gerson A. Yukio Tomanari

SÃO PAULO

2009 
Saulo Missiaggia Velasco

\section{SIMETRIA E TRANSITIVIDADE EM DISCRIMINAÇÕES CONDICIONAIS DE HUMANOS E POMBOS (COLUMBA LIVIA) AVALIADAS SOB CONDIÇÕES DE REFORÇAMENTO DIFERENCIAL}

Tese apresentado ao instituto de Psicologia da Universidade de São Paulo, como parte dos requisitos para obtenção do título de Doutor em Psicologia

Área de concentração: Psicologia Experimental

Aprovado em:

Banca examinadora

$\operatorname{Prof}(a) \cdot \operatorname{Dr}(a):$

Instituição: Assinatura:

$\operatorname{Prof}(a) \cdot \operatorname{Dr}(a)$ :

Instituição: Assinatura:

Prof(a). Dr(a):

Instituição: Assinatura:

Prof(a). Dr(a):

Instituição: Assinatura:

Prof(a). Dr(a):

Instituição: Assinatura: 
Aos meus queridos pais, Hélcio e Mika, que forneceram os alicerces da minha formação como pessoa e cientista. 


\section{AGRADECIMENTOS}

Ao Gerson Tomanari por tudo que aprendi durante os anos da minha formação como pesquisador, por acreditar no meu trabalho e me dar autonomia para desenvolvê-lo.

Ao Candido Pessôa pelas inúmeras e calorosas discussões que foram fundamentais tanto para a construção dos argumentos quanto para o refinamento conceitual deste trabalho.

Ao Edson Huziwara pela colaboração, companheirismo e intenso convívio durante toda nossa estadia na Europa.

Ao Armando Machado por me receber de portas abertas em seu laboratório durante meu estágio Sanduíche em Portugal.

Ao Andersen Picorone pela ajuda impagável com programação dos procedimentos para coleta de dados.

À Paula Debert pelas preciosas contribuições nas reuniões do laboratório e no exame de qualificação.

Aos colegas Peter Endemman e William Perez pela inúmeras discussões e elucubrações acadêmicas

Ao Marcelo Benvenuti pelo apoio em um momento crucial da realização dessa pesquisa.

À Deisy de Souza, Júlio de Rose, Olavo Galvão e Romariz Barros pelas eventuais, porém sempre valiosas discussões.

Ao Jair Lopes Junior pela cuidadosa leitura do projeto de qualificação e sugestões para o desenvolvimento da pesquisa.

Aos colegas de laboratório: Eliana Hamasaki, Viviane Rico, Nathali Sabino e Arturo 
Clavijo, bem como aos colegas agregados: Heloisa Campos, Marcelo Silveira e Rafael Modenesi pelo convívio.

Aos saudosos colegas do laboratório de Portugal: Catarina Castro, Andreia Costa, Carlos Pinto, Eugénia Fernandes, Susana Maia, José Bentes, Luís Lobo pela acolhedora recepção.

Ao Cristiano dos Santo, Alex Wahl e Paula Braga-Kenyon pelas preciosas revisões dos artigos que compõe esta tese.

Ao Altay de Sousa pela grande ajuda com as análises estatísticas.

Ao CNPq e à CAPES pelo apoio financeiro que possibilitou a realização desse trabalho.

Em especial, à minha amada esposa Tathiana Velasco por todo amor e dedicação e por estar ao meu lado em absolutamente todas as etapas da minha formação acadêmica.

Por fim, à minha estimada cadelinha Rosinha Manoela pela silenciosa companhia durante toda a escrita da tese. 
SUMÁRIO

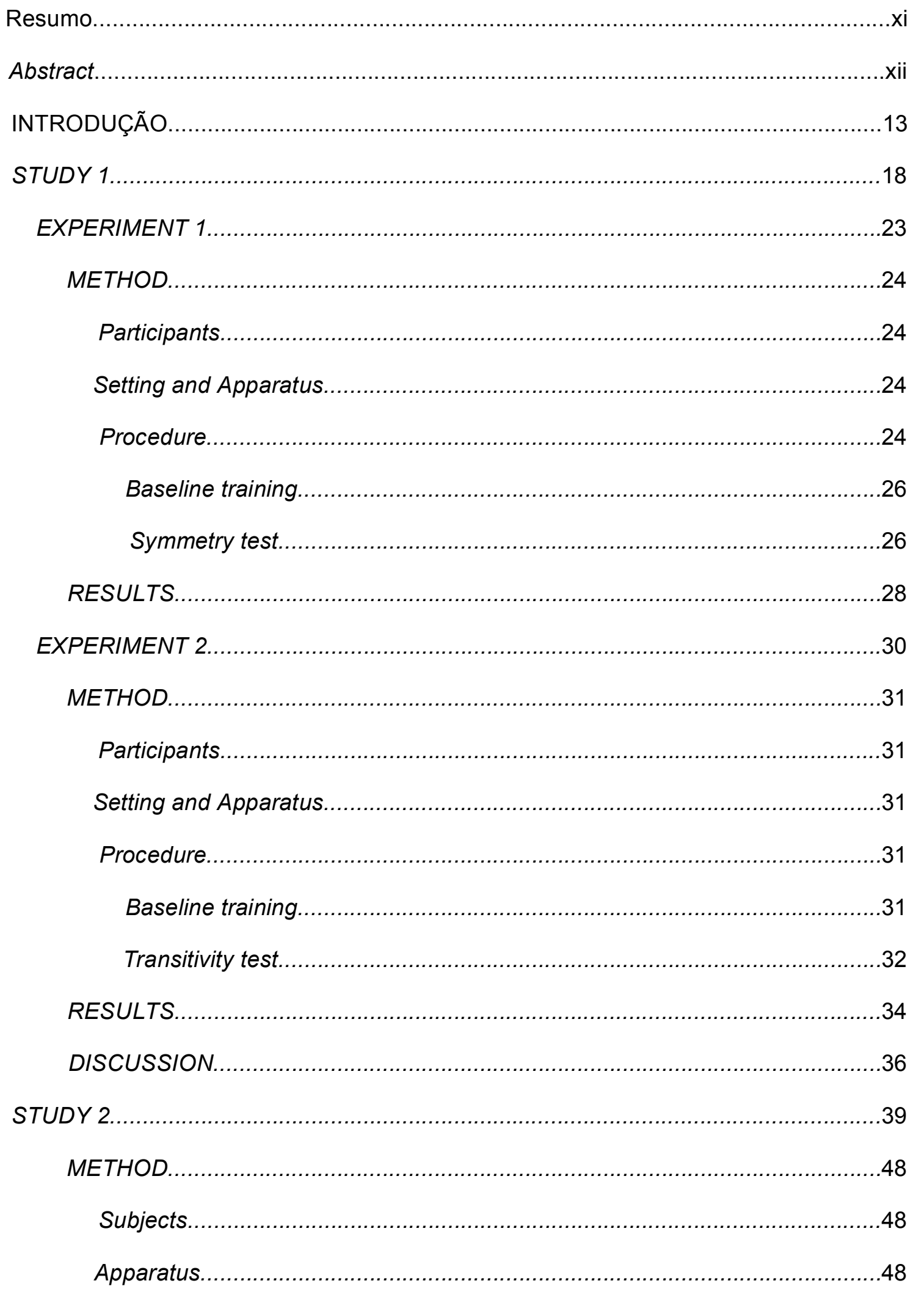




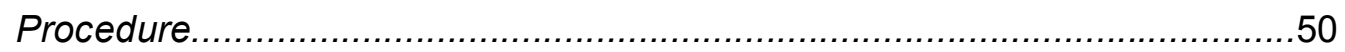

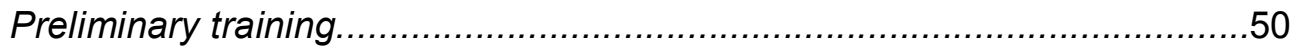

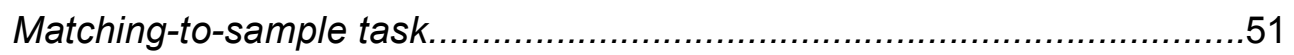

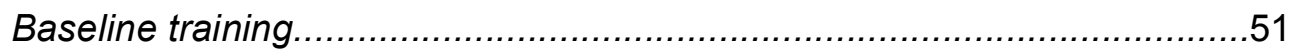

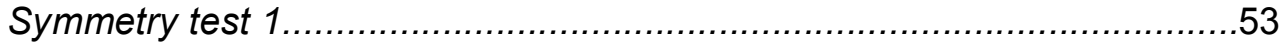

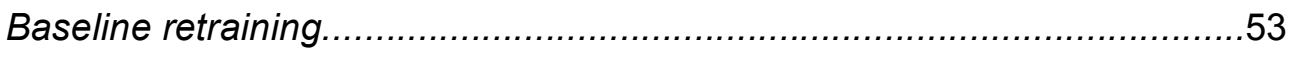

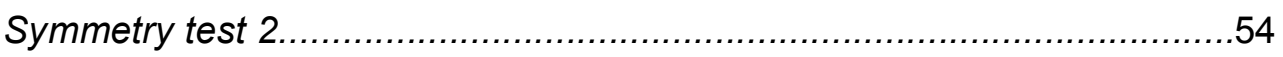

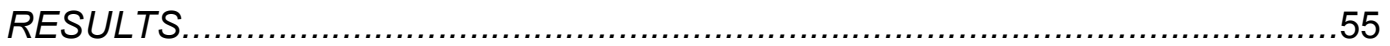

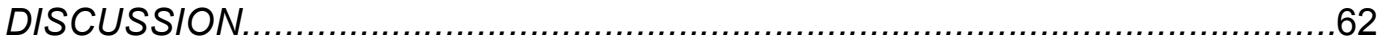

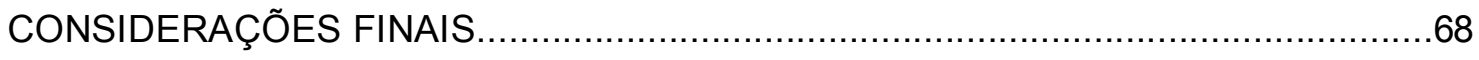

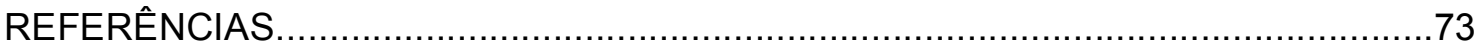




\section{LISTA DE FIGURAS}

Figure 1.1. Monochromatic representation of the 16 colored stimuli used in Experiment 1 and the 24 colored stimuli used in Experiment 2 of the Study 1. .25

Figure 1.2. Schematic representation of conditional relations reinforced in both the baseline training and the symmetry test in the Experiment 1 of the Study 1

Figure 1.3. Matching accuracy for individual participants over 48-trial blocks of the reinforced symmetry test in Experiment 1 of the Study 1

Figure 1.4. Schematic representation of the conditional relations reinforced in both the baseline training and the transitivity test in Experiment 2 of the Study 1.

Figure 1.5. Matching accuracy for individual participants over 48-trial blocks of the reinforced transitivity test in Experiment 2 of the Study 1

Figure 2.1. Graphic representation of the eight stimuli used in all experimental phases of the Study 2 .49

Figure 2.2. Matching accuracy for individual pigeons over five-session blocks of baseline training of the Study 2 . .56

Figure 2.3. Matching accuracy on the first session of the symmetry test 1 by individual pigeons of the Study 2 . .58

Figure 2.4. Matching accuracy for individual pigeons across five-session blocks in the symmetry test 1 of the Study 2 . .59

Figure 2.5. Matching accuracy on the first session of the symmetry test 2 by individual pigeons of the Study 2 . 


\section{LISTA DE TABELAS}

Table 2.1. Alphanumeric representation of the trial types presented to the pigeons in each experimental condition of the Study 2

Table 2.2. Performance of individual pigeons in the first four trials of each reinforced relation in the symmetry test 2 of the Study 2 
Velasco, S. M. (2009). Simetria e transitividade em discriminações condicionais de humanos e pombos (Columba livia) avaliadas sob condições de reforçamento diferencial. Tese de Doutorado. Instituto de Psicologia, Universidade de São Paulo. 80 p.

Resumo: A demonstração da formação de classes de equivalência é dificultada pela ausência de reforçamento durante os testes de relações emergentes que documentam suas propriedades, em particular quando se trata de sujeitos não-humanos e humanos com desenvolvimento atípico. O presente trabalho propõe uma alternativa metodológica para testar a formação de classes de equivalência sob condições de reforçamento diferencial. O primeiro estudo testou simetria e transitividade em humanos adultos verbalmente competentes com o propósito de avaliar o procedimento em condições favoráveis à demonstração da formação de classes de equivalência. $O$ segundo estudo aplicou o procedimento na avaliação de simetria em pombos. Em termos gerais, os sujeitos foram treinados em uma linha de base de relações condicionais antes de serem submetidos a testes reforçados de simetria ou transitividade. Durante o teste de simetria, dois conjuntos de relações condicionais foram adicionalmente reforçados: um constituído das contrapartes simétricas de relações da linha de base, o outro de relações inéditas não simétricas formadas pela recombinação de estímulos da linha de base. Desempenhos mais precisos nas relações simétricas em comparação às relações inéditas sugeririam um controle condicional por simetria. A mesma estratégia foi empregada para avaliar transitividade. Em relação aos resultados, os participantes humanos responderam com acurácia superior nas relações simétricas e transitivas do que nas relações inéditas no transcorrer de cada teste. Esses achados demonstram a efetividade do procedimento em avaliar a emergência de relações que definem equivalência de estímulos. Os pombos, por sua vez, desempenharam ao nível do acaso tanto nas relações simétricas quanto nas relações inéditas em um primeiro teste envolvendo a metade dos estímulos da linha de base. Entretanto, depois que essas relações foram treinadas até alta acurácia, todos os sujeitos responderam com precisão superior nas relações simétricas durante um segundo teste envolvendo os estímulos restantes da linha de base. Esses resultados contrastam a maioria dos resultados de estudos anteriores com sujeitos não-verbais e sugerem que formação de classes de equivalência pode ser verificada em tais populações sob condições adequadas de treino e teste.

Palavras-chave: discriminação condicional, equivalência de estímulos, simetria, transitividade, treino de exemplares múltiplos, testes reforçados, humanos, pombos. 
Velasco, S. M. (2009). Symmetry and transitivity in conditional discriminations of humans and pigeons (Columba livia) evaluated under differential reinforcement conditions. Ph.D. Thesis. Instituto de Psicologia, Universidade de São Paulo. 80 p.

Abstract: The lack of reinforcement in tests of emergent relations interferes with the demonstration of equivalence-class formation in nonhuman animals and humans with developmental disabilities. The present work proposes an alternative methodology to test equivalence-class formation under differential reinforcement conditions. The first study assessed symmetry and transitivity in verbally-able human adults in order to evaluate the proposed procedure. In the second study, such a procedure was applied to assess symmetry in pigeons. After subjects have been trained on the baseline conditional relations they were given either a symmetry or a transitivity reinforced test. During the symmetry test, two sets of conditional relations were additionally reinforced: symmetrical versions of the baseline relations and novel relations, formed by recombining stimuli from the baseline. Evidence for symmetry would be indicated by higher accuracies on the symmetrical than on the novel relations. Similar strategy was used to test transitivity. The results showed that human participants performed with higher levels of accuracy on the symmetrical and transitive relations than on the novel relations throughout each test. These founds indicate the efficacy of the procedure to test emergent relations that define stimulus equivalence. Pigeons, in turn, performed at chance-level in both symmetrical and novel relations in the first test involving half of the baseline stimuli. Nevertheless, after such relations have been trained to a high accuracy, all the pigeons matched at higher levels of accuracy on the symmetrical relations in the second test involving the remaining baseline stimuli. This result contrasts with the lack of symmetry reported in most of previous studies with nonverbal subjects and indicates that symmetry can emerge in such a population under adequate conditions of training and testing.

Key words: conditional discrimination, stimulus equivalence, symmetry, transitivity, multiple exemplar training, reinforced tests, humans, pigeons. 
Em muitos contextos, nos comportamos diante de palavras e outros símbolos do mesmo modo em que o faríamos se estivéssemos diante dos eventos ou objetos a que eles se referem. Isso permite, por exemplo, que aprendamos algo novo e nos comportemos adequadamente em relação a eventos ausentes ou distantes no tempo. Assim, lidamos com quantidades que estão representadas apenas por números em um papel e desviamos de um congestionamento com base em instruções ditadas por um operador de trânsito. Do mesmo modo, uma criança chora ao escutar uma história de terror e a mãe se emociona ao ler uma carta do filho distante. Tudo isso parece possível apenas porque palavras e seus referentes podem se tornar membros de uma mesma classe de estímulos equivalentes.

Em uma classe de equivalência, estímulos perceptualmente dissimilares são mutuamente substituíveis, de modo que relações condicionais não treinadas diretamente podem emergir entre os membros da classe a partir de relações que foram explicitamente reforçadas (e.g., Lazar, Davis-Lang, \& Sanches, 1984; Sidman, 1971; Sidman \& Cresson, 1973; Sidman \& Tailby, 1982). Mais que disso, funções comportamentais adquiridas individualmente por cada membro da classe podem se estender para todos os demais membros sem a necessidade de qualquer treino adicional (e.g., de Rose, Mcllvane, Dube, Galpin, \& Stoddard, 1988; Silverman, Anderson, Marshall, \& Baer, 1986).

No estudo inicial de Sidman (1971), a partir do reforçamento de relações entre palavras ditadas e figuras, bem como entre palavras ditadas e impressas, um indivíduo com retardo severo demonstrou a emergência de relações não reforçadas envolvendo figuras e palavras impressas. Além disso, uma vez que o participante já sabia nomear as figuras oralmente, ele foi capaz de ler cada palavra impressa em voz alta sem ter sido diretamente treinado nessa tarefa.

Os trabalhos iniciais de Sidman e colaboradores no início da década de 70 e a 
posterior sistematização metodológica no início da década de 80 (Sidman, Rausin, Lazar, Cunninghan, Tailby, \& Carrigan, 1982; Sidman \& Tailby, 1982) forneceram um paradigma operacional para determinar se relações arbitrárias estabelecidas em treino de discriminações condicionais são também relações de equivalência. Por exemplo, em um procedimento de emparelhamento ao modelo $\left(\mathrm{MTS}^{1}\right)$, um sujeito é treinado a escolher o estímulo de comparação B1 dado o modelo A1 e B2 dado o modelo A2, (i.e., relações condicionais $\mathrm{A}-\mathrm{B}$ ), assim com é treinado a escolher $\mathrm{C} 1$ e $\mathrm{C} 2$ dados os modelos B1 e B2, respectivamente (i.e., relações condicionais B-C). Na sequência, a formação de classes de equivalência é atestada caso o sujeito demonstre que aquelas relações inicialmente treinadas possuem as propriedades de reflexividade, simetria e transitividade. A propriedade de reflexividade é verificada pela emergência de um controle pela identidade dos estímulos, o qual é verificado caso o sujeito relacione condicionalmente cada estímulo do treino inicial a outro idêntico a ele mesmo (i.e., A-A, B-B, e C-C). Simetria é demonstrada quando dois estímulos previamente relacionados continuam a exercer controle conjunto mesmo depois que seus papéis de modelo e comparação são invertidos (i.e., B-A e C-B). Deste modo, verifica-se que as funções de modelo e comparação são intercambiáveis entre os estímulos condicionalmente relacionados. A propriedade de transitividade é demonstrada pela emergência de uma relação envolvendo dois estímulos nunca antes relacionados entre si (i.e., A-C), mas que, em contrapartida, foram relacionados a um terceiro estímulo em comum. Em todos esses casos, as relações emergentes que documentam as propriedades definidoras da equivalência são avaliadas na ausência de qualquer reforçamento programado.

Por envolver relações arbitrárias, intercambialidade de funções e emergência de relações não treinadas entre estímulos, a formação de classes de equivalência tem sido apontada como um requisito comportamental crítico para o desenvolvimento de

1 Do inglês matching-to-sample. 
funções cognitivas complexas como formação de conceitos, categorização simbólica e linguagem (e.g., de Rose, 1993; Galvão, 1993; Mackay, \& Sidman, 1984; Schusterman \& Kastak, 1993; Sidman, 1994). Na prática, a aplicação do modelo de equivalência na análise da comunicação simbólica e na explicação da emergência de comportamentos novos no repertório dos organismos tem conduzido ao desenvolvimento de um corpo conceitual e metodológico empiricamente consistente para lidar com fenômenos comportamentais complexos a partir da perspectiva científica da Análise Experimental do Comportamento.

Nesses quase quarenta anos que se sucederam ao primeiro estudo de Sidman (1971), a pesquisa em equivalência de estímulos tem se concentrado em pelo menos dois eixos ou níveis de investigação. De um lado, impulsionados pelo estudo inicial de Sidman, muitos esforços têm sido destinados à produção de tecnologias comportamentais para o ensino de leitura e escrita a indivíduos apresentam dificuldade em aprender pelos métodos tradicionais de ensino (e.g., de Rose, de Souza, \& Hanna, 1996; de Rose, de Souza, Rossito, \& de Rose, 1989; de Souza \& de Rose, 2006; Matos, Peres, Hübner, \& Malheiros, 1997; Medeiros, Antonakopoulu, Amorim, \& Righetto, 1997; Melchiori, de Souza, \& de Rose, 2000). De outro lado, diante dos repetidos insucessos em demonstrar a formação de classes de equivalência em organismos não-verbais, sobretudo em não-humanos, a busca por refinamentos metodológicos que possibilitem tal demonstração tem sido incessante (e.g., D'Amato, Salmon, Loukas, \& Tomie, 1985; Frank \& Wasserman, 2005; LionelloDeNolf \& Urcuioli, 2002; Lipkens, Kop, \& Matthijs, 1988; Schusterman \& Kastak, 1993; Sidman et al., 1982; Tomonaga, Matsuzawa, Fujita, \& Yamamoto, 1991, Urcuioli, 2008; Yamamoto \& Asano, 1995).

Essa discrepância entre os resultados obtidos com sujeitos verbais e não-verbais tem sido palco de um caloroso debate a respeito do papel da linguagem na formação de 
classes de equivalência. Por um lado, os inúmeros insucessos obtidos com sujeitos nãoverbais poderiam indicar que a formação de classes de equivalência estaria condicionada à aquisição de competências lingüísticas, e não o contrário (cf. Devany, Hayes, \& Nelson, 1986; Dugdale \& Lowe, 2000; Hayes, 1989; Hayes, Barnes-Homes, \& Roche, 2001). Por outro lado, para os que consideram que equivalência possa constituir as próprias bases do desenvolvimento da linguagem, as dificuldades em tal demonstração refletiriam a inadequação dos procedimentos às especificidades de cada organismo estudado (cf. Dube, Mcllvane, Callahan, \& Stoddard, 1993).

Independentemente de qualquer teorização acerca das relações envolvendo equivalência de estímulos e linguagem, a busca por um modelo animal para o estudo da formação de classes de equivalência e a conseqüente identificação das condições necessárias e suficientes para sua ocorrência em organismos não-verbais trarão contribuições imediatas para o ensino de competências lingüísticas a indivíduos com necessidades educacionais especiais. Assim, o presente trabalho busca aprimorar uma estratégia metodológica por meio da qual a formação de classes de equivalência possa ser avaliada sob condições permanentes de reforçamento diferencial, uma vez que com tais populações essa avaliação parece prejudicada pela ausência de reforçamento que vigora durante os testes (e.g., Devany et al., 1986; Kuno, Kitadate, \& Iwamoto, 1986; Sidman et al., 1982; Tomonaga et al., 1991, Yamamoto \& Asano, 1995). Dando continuidade aos trabalhos de Velasco e Tomanari (2008; 2009) a presente investigação pretende fornecer subsídios tanto para a produção de tecnologias de ensino dirigidas a populações com as quais os testes em extinção imprimem dificuldades, quanto para a investigação dos requisitos onto- e filogenéticos da formação de classes de equivalência em animais não-humanos.

A seguir, serão descritos dois estudos que exemplificam esses esforços. $O$ primeiro, projetado para testar simetria e transitividade em humanos adultos 
verbalmente competentes, tratou do desenvolvimento da metodologia e de sua validação pela comparação de seus resultados com aqueles produzidos utilizando-se o paradigma tradicional de equivalência de estímulos. O segundo envolveu a aplicação dessa metodologia na busca pela demonstração de simetria em pombos. Embora metodologicamente relacionados, os estudos são independentes entre si de modo que serão apresentados separadamente como dois artigos distintos. Sob o ônus de parecer redundante, mas a fim de se preservar a coesão interna de cada estudo, eventuais repetições de temas considerados centrais não puderam deixar de ocorrer, embora tenham sido abordados em diferentes níveis de aprofundamento em cada artigo. 


\section{STUDY 1}

\section{Testing Symmetry and Transitivity under Differential Reinforcement Conditions}

Abstract: A new strategy is proposed to evaluate the effects of baseline conditional discrimination training on the emergence of its correspondent symmetrical and transitive relations. Experiment 1 evaluated symmetry. Four verbally able adults were trained on two independent baseline-matching tasks (A-B and C-D). Next, two sets of testing relations were reinforced for each participant - symmetrical versions of the baseline relations (BA and $D C)$ and novel recombinations of the baseline stimuli (BC and AD). All the participants showed high levels of accuracy in the symmetrical relations in the first test block and performed approximately at chance in the novel relations. Additionally, they all reached the performance criterion for the symmetrical relations earlier than for the novel relations. Experiment 2 assessed transitivity. Two sets of interconnected baseline matching tasks (AB-BC and DE-EF) were trained, following by the reinforcement of two sets of testing relations - transitive (AC and DF) and novel (AF and DC) with respect to the baseline. All but one of the participants was more accurate for the transitive relations in the first test block, and reached the accuracy criterion earlier than they did for the novel relations. Comparative analysis between individual performances on both sets of testing relations showed symmetry and transitivity under differential reinforcement conditions.

Key words: conditional discrimination, stimulus equivalence, arbitrary matchingto-sample, symmetry, transitivity, reinforced tests, button press, humans. 
A subject taught to relate physically dissimilar stimuli can establish new conditional relations among them without any additional training (Sidman, Kirk, \& Willson-Morris, 1985; Sidman \& Tailby, 1982; Sidman, Willson-Morris, \& Kirk, 1986; Spradlin, Cotter, \& Baxley, 1973). The emergence of conditional relations not directly trained has been taken as evidence of equivalence-class formation (Sidman et al., 1982; Sidman \& Tailby, 1982). According to this paradigm, following reinforcement for choosing $B$ after $A$ and $C$ after $B$ (i.e., $A-B$ and $B-C$ baseline training), the formation of an equivalence class is verified when - in the absence of any scheduled differential reinforcement - a subject shows the emergence of untaught conditional relations that indicate the properties of reflexivity $(A-A, B-B$, and $C-C)$, symmetry $(B-A$ and $C-B)$, and transitivity $(\mathrm{A}-\mathrm{C})$.

Experimental results have shown equivalence-class formation in human subjects with typical or atypical development (Devany, et al., 1986; Lazar et al., 1984; Sidman \& Cresson, 1973; Sidman \& Tailby, 1982; Spradlin et al., 1973). In contrast, among nonhuman animals and even nonverbal humans, it has proven difficult to demonstrate equivalence-class formation (e.g., D'Amato et al., 1985; Devany et al., 1986; Hogan \& Zentall, 1977; Lionello-DeNolf \& Urcuioli, 2002; Lipkens, et al., 1988; Sidman et al., 1982; Tomonaga, et al., 1991; Yamamoto \& Asano, 1995).

On the one hand, the demonstration of stimulus equivalence may involve behavioral prerequisites that humans could have acquired in preexperimental contingencies. Some researchers suggest, for instance, that linguistic abilities could be a necessary prerequisite for demonstrating emergent relations (Devany et al., 1986; Dugdale \& Lowe, 2000; Hayes, 1989; Hayes et al., 2001). On the other hand, it has also been argued that stimulus equivalence could constitute the basic foundations of language development, and not the inverse (Galvão, 1993; Mackay \& Sidman, 1984; Schusterman \& Kastak, 1993). Sidman (1990; 1994; 2000), for example, suggests that 
equivalence could be a basic stimulus function and, therefore, not derived from other behavioral processes. In this case, the difficulty in demonstrating equivalence-class formation in nonverbal humans and nonhuman animals would have methodological roots, such as inadequate training or testing conditions, or both (cf. Dube et al., 1993).

Methodologically, the lack of differential reinforcement during equivalence tests may constitute an important variable responsible for the negative results usually reported with these populations. Compared to the former training situation, the extinction condition employed in testing may change significantly the sources of stimulus control, thus preventing the emergence of conditional relations consistent with equivalence-class formation (Dube \& Mcllvane, 1996; Galvão, Calcagno, \& Sidman 1992; Kuno et al., 1994; Schusterman \& Kastak, 1993; Sidman, 1994; Sidman et al., 1982). Moreover, the suspension of the reinforcement is usually accompanied by resurgent behavior (Villas-Boas, Murayama, \& Tomanari, 2005, Wilson \& Hayes, 1996) and other behavioral effects, such as aggression and agitation (Azrin, Hutchinson \& Hake, 1966), responses of physical attack, urination and defecation (Keller \& Schoenfeld, 1950; Skinner, 1938), as well as increases in behavioral variability (Antonitis, 1951; Lerman \& Iwata, 1996). All of these effects can, in some way, interfere with the demonstration of the testing relations, especially given that the lack of reinforcement in testing reproduces the same consequences of incorrect responses during the baseline training.

The observation of negative effects in conducting testing in the absence of reinforcement has incited the development of methodological strategies that allow for the evaluation of equivalence properties under differential reinforcement conditions (e.g., D'Amato et al., 1985; Urcuioli, Zentall, Jackson-Smith, \& Steirn, 1989). Usually, after the acquisition of the baseline training relations, subjects' performances are compared across reinforced test trials of conditional relations that are either consistent 
or inconsistent with equivalence-class formation. For example, to evaluate transitivity, following the training of $A 1-B 1, A 2-B 2, B 1-C 1$ and $B 2-C 2$ relations, subjects are exposed to the reinforcement of $\mathrm{A} 1-\mathrm{C} 1$ and $\mathrm{A} 2-\mathrm{C} 2$ relations (both consistent with the formation of $\mathrm{A} 1 \mathrm{~B} 1 \mathrm{C} 1$ and $\mathrm{A} 2 \mathrm{~B} 2 \mathrm{C} 2$ classes), as well as to the reinforcement of $\mathrm{A} 1-\mathrm{C} 2$ and $\mathrm{A} 2-\mathrm{C} 1$ relations (both inconsistent with the formation of such classes). A similar strategy can be applied to evaluate symmetry.

Both group- and single-subject designs are used in the comparison of consistent and inconsistent reinforced testing relations. In the former case, following the baseline training, subjects are divided into two experimental groups. One group is exposed to the reinforcement of consistent relations, the other to that of inconsistent relations. The accuracy in the first test session, or the acquisition speed of the reinforced relations, is compared between the two groups of subjects. In making use of this type of design in a study with twelve pigeons, Urcuioli et al. (1989) reported that consistent transitivity-like relations were acquired faster than inconsistent relations. In a single-subject design, the same organism is exposed to the reinforcement of these two sets of conditional relations (consistent and inconsistent with equivalence-class formation). D'Amato et al. (1985), using this type of experimental design, evaluated transitivity in three pigeons as well as symmetry and transitivity in six nonhuman primates. The pigeons showed no difference in performance accuracies in the consistent and inconsistent relations. In contrast, nonhuman primates systematically showed a more accurate and accelerated acquisition of conditional relations consistent with transitivity, but not with symmetry.

Despite the clear advantage in conserving differential reinforcement during equivalence tests, the reinforcement of inconsistent relations can confound the interpretation of results in single-subject designs. To the extent that the same stimuli integrate both consistent (e.g., $\mathrm{A} 1 \mathrm{C} 1$ and $\mathrm{A} 2 \mathrm{C} 2$ ) and inconsistent (e.g., $\mathrm{A} 1 \mathrm{C} 2$ and 
A2C1) relations, the reinforcement of those inconsistent relations could merge these stimuli into a single large class (e.g., A1A2B1B2C1C2). This merge could result in chance-level performances in both consistent and inconsistent relations, as one can see in the data of some subjects of D'Amato et al. (1985).

In light of this fact, the present study proposes an alternative methodology for assessing symmetry and transitivity under differential reinforcement conditions. The procedure employs a single-subject design (cf. D'Amato et al., 1985; unlike Urcuioli et al., 1989) and abandons the use of inconsistent conditional relations (unlike D'Amato et al., 1985 and Urcuioli et al., 1989). Instead, reinforced-test relations consistent with equivalence-class formation are compared to novel (not inconsistent) reinforced relations formed by recombining familiar stimuli from the baseline training. 


\section{EXPERIMENT 1}

Participants were initially trained on two independent arbitrary-matching tasks (A-B and $C-D$ ) involving four stimuli sets. Afterwards, a reinforced symmetry test was conducted with Set-1 and Set-2 stimuli $\left(B_{1-2}-A_{1-2}\right.$ and $\left.D_{1-2}-C_{1-2}\right)$. Additionally, two novel relations (not inconsistent) were concurrently reinforced by recombining stimuli from Set-3 and Set-4-baseline relations $\left(D_{3-4}-A_{3-4}\right.$ and $\left.B_{3-4}-C_{3-4}\right)$ in order to control for the effects of direct training of the symmetrical relations due to reinforcement in test trials. If symmetry emerges, then first-test-session accuracies should be above chance on the symmetrical relations and at chance on the novel relations. In addition, participants would learn the symmetrical relations faster than the novel relations over repeated test sessions. 


\section{METHOD}

\section{Participants}

Four undergraduate students ( 3 females and 1 male) at the University of Minho in Portugal were volunteers in this experiment. They were drawn from journalism and biology courses. None had prior familiarity with the experimental analysis of behavior.

\section{Setting and Apparatus}

The research was conducted in a room containing four experimental stations separated from each other by an opaque divider. Several subjects participated simultaneously and were instructed not to talk while in the experiment room. Each experiment station was equipped with a microcomputer, an LCD video monitor, a mouse and an earphone. The computers controlled experimental contingencies and recorded data through a software developed for this study (Stimulus Control 1.002). Sixteen colored visual stimuli, superimposed on a white background, were divided randomly into four 4-stimuli set (Figure 1.1).

\section{Procedure}

Two experimental phases were conducted with each participant (baseline training and symmetry test). In both phases, participants were exposed to a zerosecond-delayed arbitrary matching-to-sample procedure. Each trial began with the onset of the sample in the center of the screen. A response to the sample, accomplished by moving the cursor over the stimulus and pressing the left mouse button, replaced this screen with a new one in which four different comparison stimuli appear simultaneously in each of the four corners of the screen. A response to the 
stimulus arbitrarily set as the correct comparison made all of them disappear, produced a sound in the earphones ("beep"), and increased by a value of one a counter located at the center-top portion of the screen. Such a selection was considered a correct response. A response to any of the other three stimuli ended the trial with the disappearance of the comparisons. Such a selection was considered an incorrect response. Between every two trials, there was a 0.5 second Inter-Trial Interval (ITI), during which the screen remained blank. There were no scheduled consequences for responses on the screen during the ITI.

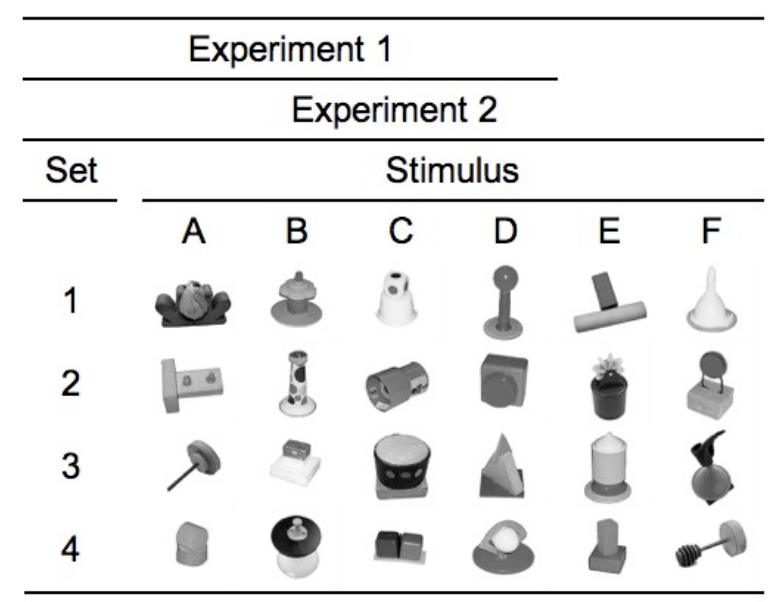

Figure 1.1. Monochromatic representation of the 16 colored stimuli used in Experiment $1(A, B, C$ and $D)$, and the 24 colored stimuli used in Experiment $2(A, B, C, D, E$ and F) of the Study 1. Stimuli component of each set were counterbalanced across participants. Only sample-comparison relations between stimuli from the same set were reinforced during each experiment. This information was available only to the experimenter.

Each training and testing session consisted of 192 trials divided into four blocks of 48 trials. Each 48-trial block comprised six trials for each of the eight conditional relations trained in each phase (see procedure below). These trials were presented in a 
semi-random order inside of each block according to the following criteria: 1) each comparison location received the same number of correct comparisons (12 scheduled reinforcements in each corner); 2) reinforcement in the same location was repeated in a maximum of two consecutive trials; 3 ) a given conditional relation was repeated in a maximum of two consecutive trials.

At the beginning of the experiment, each participant was given the following written instruction (translated from the Portuguese): "This study is not about intelligence testing, and will not evaluate any aspect of your intellectual abilities. When it finished you will receive a full explanation. Please, do not to talk while in the experiment room. An image will be presented in the center of the screen. Your task is click, with the mouse, in this image. Then, four different images will be presented in the corners of the screen. Your task is select one of those images and click in it with the mouse. During the task, you will sometimes receive and sometimes not receive points. Your aim is to earn the maximum points as you can. Please, repeat to me the instructions you just read."

Baseline training. With the procedure just described, eight baseline conditional relations were concurrently trained for each participant in two independent matching tasks (top panel of Figure 1.2). On half of the trials, B comparisons were conditionally related to A samples. On the remaining trials, D comparisons were conditionally related to $C$ samples (i.e., $A-B$ and $C-D$ matching). Training sessions lasted until participants met the criterion of $100 \%$ accuracy in two consecutive 48-trial blocks within the same session.

Symmetry test. After participants met the accuracy criterion in baseline training, 
they were tested for symmetry with samples from the baseline being used as comparisons, and vice-versa (bottom panel of Figure 1.2). Test performances were differentially reinforced. On half of the trials, reinforced sample-comparison relations were the symmetrical versions of half of baseline relations - matching A1 and A2 comparison to $\mathrm{B} 1$ and $\mathrm{B} 2$ samples, respectively, as well as matching $\mathrm{C} 1$ and $\mathrm{C} 2$ comparisons to D1 and D2 samples (B-A and D-C matching). In order to control for the effects of reinforcement of the symmetrical relations, four novel relations were reinforced on the remaining trials by recombining stimuli from the remaining baseline relations - matching A3 and A4 comparisons to D3 and D4 samples, respectively, as well as matching $\mathrm{C} 3$ and $\mathrm{C} 4$ comparisons to $\mathrm{B} 3$ and $\mathrm{B} 4$ samples (D-A and $\mathrm{B}-\mathrm{C}$ matching). Symmetrical and novel relations were concurrently reinforced over the course of repeated test sessions until the participant met the same accuracy criterion described above for the baseline training.

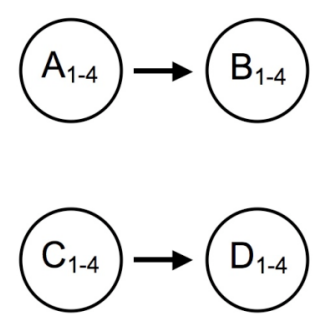

Baseline relations

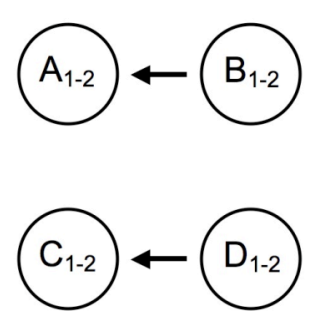

Symmetrical relations

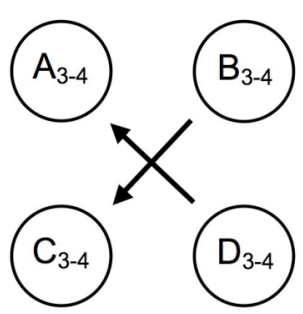

Novel relations

Figure 1.2. Schematic representation of conditional relations reinforced in both the baseline training (top panel) and the symmetry test (bottom panel) in the Experiment 1 of the Study 1. Arrows point from sample to comparison stimuli. 


\section{RESULTS}

Baseline training. Participants DAC, NAA, ALC and PAR required a total of 8 , 10,12 and 11 blocks of 48 trials, respectively, to meet the accuracy criterion in the baseline training. Acquisition of baseline relations trained with Set-1 and Set-2 stimuli was compared with the acquisition of those trained with Set-3 and Set-4 stimuli, and no significant difference was found with respect to the number of sessions required for participants to reach the performance criterion on both groups of relations $(Z<.001, p$ = 1). The mean number of sessions to reach the specified criterion was 10 for Set-1 and Set-2 relations (range, 8 to 12) as well as for Set-3 and Set-4 relations (range, 7 to 11). Moreover, accuracies on Set-1- and Set-2-relation trials did not differ significantly from accuracies on Set-3- and Set-4-relation trials across training sessions $(Z=-$ $1.443, p=.149)$.

Such results represent an important control for the reinforced symmetry test since symmetrical and novel relations were drawn from different sets of stimuli. Whereas the symmetrical relations were formed with Set- 1 and Set- 2 stimuli, the novel relations were formed with Set-3 and Set- 4 stimuli. Thus possible higher accuracies on the symmetrical-relation than on the novel-relation trials could not be attributed to unknown variables, such as inherent stimulus properties.

Symmetry test. Figure 1.3 shows individual matching accuracy over blocks of 48 trials throughout the symmetry test when the reinforced test relations were the symmetrical versions of the baseline relations or novel combinations of baseline stimuli. All the participants performed well above chance-level on the symmetricalrelation trials in the first 48 -trial block (range, $83 \%$ to $100 \%$ ). From the second block 
onwards, all participants matched at $100 \%$ of accuracy in the symmetrical-relation trials (except for DAC, who did so on the very first 48-trial block). In contrast, accuracy levels on the novel relations were below chance for participants NAA and ALC (42\% correct for both), and slightly above chance for participants DAC and PAR (67\% and 63\% correct, respectively) in the first 48-trial block. Performance accuracy on novel relations increased abruptly to $100 \%$ correct for participants DAC and NAA (in two trial blocks), while it increased only gradually for ALC and PAR (in four and six trial blocks, respectively). Matching accuracies in the symmetrical-relation trials were significantly higher than in the novel-relation trials throughout test sessions $(Z=-2.809, p=.005)$.

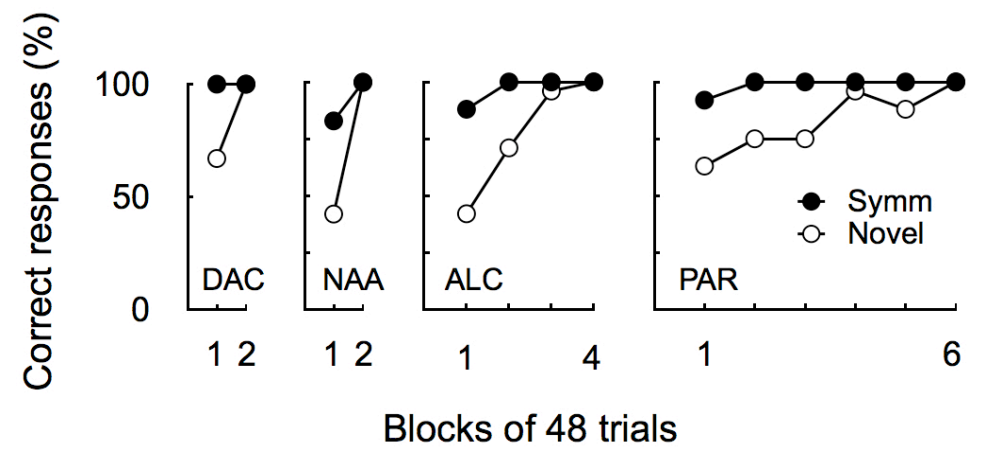

Figure 1.3. Matching accuracy for individual participants over 48-trial blocks of the reinforced symmetry test in Experiment 1 of the Study 1. Reinforced relations were either symmetrical (solid circles) or novel (open circles) with respect to the baseline training relations. 


\section{EXPERIMENT 2}

Experiment 2 was conducted in order to assess transitivity. Participants were initially trained on two independent sets of interconnected arbitrary relations (A-B B-C and D-E E-F). Next, a reinforced transitivity test was given with Set-1 and Set-2 stimuli $\left(A_{1-2}-C_{1-2}\right.$ and $\left.D_{1-2}-F_{1-2}\right)$. In order to control for the effects of reinforcement in test trials, two novel relations (not inconsistent) were concurrently reinforced by recombining stimuli from Set-3- and Set-4-baseline relations $\left(A_{3-4}-F_{3-4}\right.$ and $\left.D_{3-4}-C_{3-4}\right)$. Evidence of transitivity would be indicated by first-test-session accuracies above chance on the transitive relations and at chance on the novel relations. In addition, transitive relations should be learned faster than the novel relations over repeated test sessions. 


\section{METHOD}

\section{Participants}

Four undergraduate students (2 females and 2 males) at the University of Minho in Portugal were volunteers in this experiment. They were recruited from journalism and history courses and had no prior familiarity with the experimental analysis of behavior.

\section{Setting and Apparatus}

Setting and apparatus were the same as those used in Experiment 1. Twentyfour colorful visual stimuli, superimposed on a white background, were divided randomly into four six-stimulus sets (Figure 1.1).

\section{Procedure}

Each participant was exposed to two experimental phases (baseline training and transitivity test). With the exception of the reinforced conditional relations, all of the parameters of the matching-to-sample procedure were identical to those described in Experiment 1.

Baseline training. Participants were concurrently trained for sixteen baseline conditional relations, divided into two sets of interconnected matching tasks (top panel of Figure 1.4). In one set, $B$ and $C$ comparisons were conditionally related to $A$ and $B$ samples, respectively (A-B and $B-C$ matching). In the other set, $D$ and $E$ samples were conditionally related to $E$ and $F$ comparisons, respectively ( $D-E$ and $E-F$ 
matching). Each training session was composed of 192 trials, further divided into blocks of 48 trials. Each 48-trial block comprised three trials for each conditional relation. These 48 trials were presented in a semi-random order according to the criteria previously described in Experiment 1. Participants were trained until they reach the accuracy criterion (100\% correct) in four consecutive 48-trial blocks within the same session.

$$
\begin{gathered}
\mathrm{A}_{1-4} \rightarrow \mathrm{B}_{1-4} \rightarrow \mathrm{C}_{1-4} \\
\text { Baseline relations }
\end{gathered}
$$

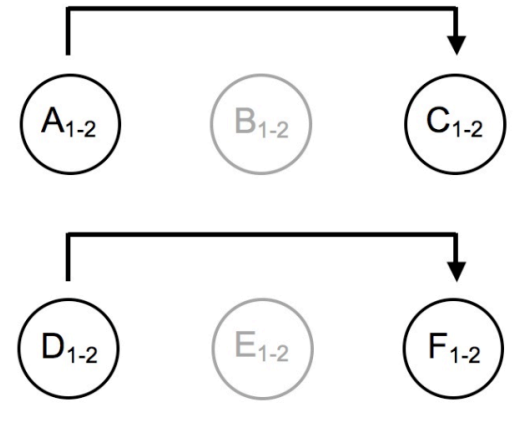

Transitive relations

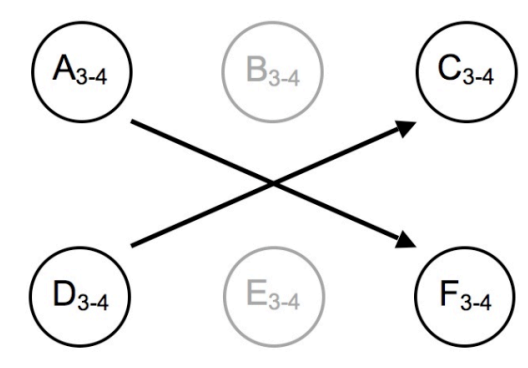

Novel relations

Figure 1.4. Schematic representation of the conditional relations reinforced in both the baseline training (top panel) and the transitivity test (bottom panel) in Experiment 2 of the Study 1. Arrows point from samples to comparisons.

Transitivity test. Once participants met the accuracy criterion in baseline training, they were given a reinforced test in which transitive and novel relations were concurrently reinforced (bottom panel of Figure 1.4). Transitive relations comprised stimuli that had been related to a third stimulus in common during the baseline training 
- matching $\mathrm{C} 1$ and $\mathrm{C} 2$ comparison to $\mathrm{A} 1$ and $\mathrm{A} 2$ samples, respectively, as well as matching $F 1$ and $F 2$ comparisons to $D 1$ and D2 samples, respectively (A-C and D-F matching). Novel relations were constituted by recombining stimuli that had not been previously related to any stimulus in common - matching F3 and F4 comparison to A3 and A4 samples, respectively, as well as matching C3 and C4 comparisons to D3 and D4 samples, respectively ( $A-F$ and $D-C$ matching). Such relations were trained in order to control for the effects of the reinforcement of the transitive relations. Each session had 192 trials divided into blocks of 48 trials. Each 48 -trial block comprised six trials of each conditional relation. Testing sessions were conducted until participants met the accuracy criterion ( $100 \%$ correct responses) in two consecutive trial blocks within the same session. 


\section{RESULTS}

Baseline training. Participants JOO, TIS, MEG and TAB reached performance criterion on baseline training in 12, 24, 21 and 47 blocks of 48 trials, respectively. The number of sessions required for participants to reach the performance criterion on Set1- and Set-2-baseline relations was not significantly different from that on Set-3 and Set-4 relations $(Z=-1.414, p=.157)$. The mean number of sessions to reach the performance criterion was 26 for Set- 1 and Set-2 relations (range, 11 to 47 ) as well as for Set-3 and Set-4 relations (range, 12 to 47). Furthermore, accuracies on Set-1- and Set-2-relation trials did not differ significantly from accuracies on Set-3- and Set-4relation trials across training sessions $(Z=-.767, p=.443)$.

Transitivity test. Figure 1.5 shows individual matching accuracy over 48-trial blocks of the transitivity test, when the reinforced relations were either transitive or novel with respect to the baseline relations. Performance accuracy on the transitive relations was higher than on the novel relation across all 48-trial blocks for Participants JOO, TIS and MEG. Both JOO and TIS matched well above chance-level in the transitive-relation trials in the first 48 -trial block (92\% and $96 \%$ correct, respectively), reaching $100 \%$ accuracy on the second block. Regarding the novel relations, JOO performed $75 \%$ and $100 \%$ correct in the first and second 48 -trial blocks, respectively. TIS, in turn, performed below chance-level (42\% correct) on the novel relations in the first 48-trial block, and reached $100 \%$ accuracy after five blocks. Performance of MEG on the transitive-relation trials increased from $79 \%$ to $100 \%$ accuracy in the first three 48-trial blocks, while, on the novel-relation trials, she required eight blocks to improve accuracy from $42 \%$ to $100 \%$. In contrast, Participant TAB performed considerably below that of chance-level $(21 \%$ correct) with respect to the transitive relations and 
slightly below chance $(42 \%$ correct) with respect to the novel relations, in the first $48-$ trial block. Performance accuracy of TAB fluctuated with respect to both the transitive and novel relations, increasing only gradually across eight 48-trial blocks. In general, matching accuracies in the transitive-relation trials were significantly higher than in the novel-relation trials throughout test sessions for all participants $(Z=-2.019, p=.044)$.

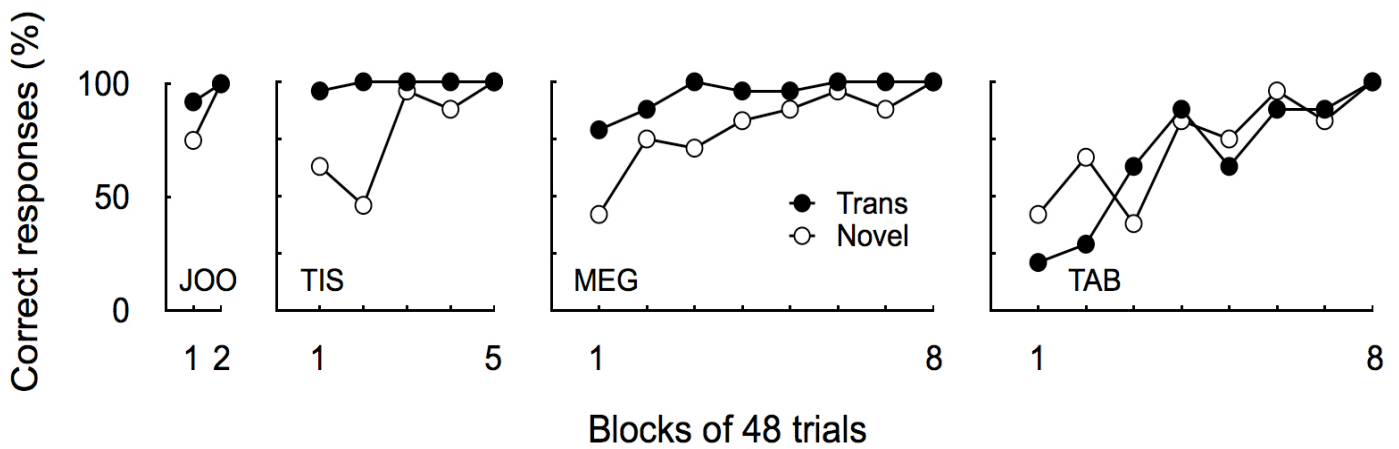

Figure 1.5. Matching accuracy for individual participants over 48-trial blocks of the reinforced transitivity test in Experiment 2 of the Study 1. Reinforced test relations were either transitive (solid circles) or novel (open circles) with respect to the baseline training relations. 


\section{DISCUSSION}

Several studies on stimulus equivalence (Sidman et al., 1982; Sidman \& Tailby, 1982) have shown that, having learned a certain number of conditional relations, verbally able subjects can show new derived conditional relations that have never been explicitly reinforced (e.g., Devany et al., 1986; Lazar et al., 1984; Sidman \& Cresson, 1973; Sidman et al., 1985; Sidman \& Tailby, 1982; Spradlin et al., 1973). According to this paradigm, the emergence of conditional relations that document the properties of reflexivity, symmetry and transitivity indicates the formation of equivalence classes. Although assessing these properties in extinction conditions is important in revealing an emergent relational performance, suspending the differential reinforcement during testing can preclude the demonstration of equivalence-class formation in nonverbal humans, as well as in nonhuman subjects (Dube \& Mcllvane, 1996; Galvão et al., 1992; Kuno et al., 1994; Sidman et al., 1982).

The present study proposed a new methodological strategy to evaluate equivalence-class formation under differential reinforcement conditions. In Experiment 1 , which was designed to assess symmetry, participants initially received a baseline conditional relation training. Next, during the symmetry test, two sets of conditional relations were additionally reinforced for each participant. One set (symmetrical relations) was constituted by reversing the roles of samples and comparisons from half of the baseline relations. The other set (novel relations) was formed by recombining stimuli from the remaining half of the baseline relations. In Experiment 2, after having acquired the baseline relations, participants were exposed to the reinforcement of conditional relations both transitive and novel with respect to the baseline. Although conditional relations that could document the properties of symmetry and transitivity were reinforced directly, performance of each participant with respect to both sets of 
relations was compared with his or her own performance during the training of novel conditional relations.

All of the participants in Experiment 1 demonstrated high levels of accuracy in the symmetrical-relation trials in the first reinforced test block, while they performed only around chance in the novel-relations trials. In addition, each participant reached performance criterion with respect to symmetrical relations earlier than to novel relations. In Experiment 2, all but one participant (TAB) demonstrated greater accuracy with respect to the transitive relations in the first trial block, and reached accuracy criterion in a fewer number of trials than they did with respect to the novel relations. This set of results, which is in agreement with the literature (e.g., Devany et al., 1986; Lazar et al., 1984; Sidman \& Cresson, 1973; Sidman \& Tailby, 1982; Spradlin et al., 1973) suggests the emergence of symmetry and transitivity in verbally competent human subjects. The fact that one participant in Experiment 2 did not exhibit evidence of transitivity also reveals parallels with previous studies that showed that, even in humans, the emergence of conditional relations can be delayed, dependent on remediating procedures, or in fact may never be obtained (Lazar, 1977; Lazar et al., 1984; Sidman et al., 1985, 1986; Spradlin et al., 1973).

In order to validate the proposed methodological strategy, the present study was conducted using verbally able adults in light of the fact that equivalence-class formation is easily demonstrated with such a population. Thus, the comparison between the present results and those from the established literature reveals the potential for the proposed procedure to demonstrate equivalence-class formation under differential reinforcement condition. Moreover, the present investigation provides parameters for subsequent studies with organisms in which such a demonstration seems to be affected by the exposure to extinction tests. In the present proposal, many of the negative consequences of testing equivalence-class formation in the absence of 
differential reinforcement were avoided. In the laboratory, this fact could have immediate implications for the demonstration of stimulus equivalence in nonhuman animals and nonverbal humans, thus contributing to the epistemology of symbolic communication. In the applied field it could contribute to the development of behavioral techniques to teach reading and writing competences to individuals who presented difficulty in learning by the traditional methods. 


\section{STUDY 2}

\section{Associative Symmetry by Pigeons after a Few-exemplar Training}

Abstract: The present experiment investigated whether pigeons can show associative symmetry in a two-alternative matching-to-sample procedure after a sequence of training and testing that provided exemplars of reinforced symmetrical relations, as well as all prerequisite discriminations among test samples and comparisons. After pigeons had learned two arbitrary-matching tasks ( $A-B$ and $C-D)$, they were given a reinforced symmetry test for half of the baseline relations (B1-A1 and D1-C1). Two novel relations were concurrently reinforced using familiar stimuli from the remaining baseline relations (D2-A2 and B2-C2) to control for the effects of reinforcement in test trials. Pigeons matched at chance in both symmetrical- and novel-relation trials thus indicating no evidence of emergent symmetry. Both the symmetrical and novel relations were then trained to a high accuracy before a second symmetry test was given with stimuli that first integrated the symmetrical relations being now recombined on novel relations, and viceversa. Once the first reinforced symmetry test provided experience of samples and comparisons switching roles, as well as all prerequisite discriminations among current samples and comparisons, pigeons performed more accurately in the symmetricalrelation trials (B2-A2 and $\mathrm{D} 2-\mathrm{C} 2)$ than in the novel-relation trials (D1-A1 and $B 1-C 1)$ during this second symmetry test. This result contrasts with the lack of symmetry reported in most of previous studies with nonhuman animals and indicates that symmetry can emerge in pigeons under adequate conditions of training and testing.

Key words: associative symmetry, stimulus equivalence, exemplar training, twoalternative matching-to-sample, reinforced tests, key peck, pigeons. 
A subject taught to relate perceptually dissimilar stimuli in a matching-to-sample (MTS) task can establish new conditional discriminations among them without any additional training. For example, following reinforcement for choosing B1 and B2 comparisons given $A 1$ and $A 2$ samples, respectively ( $A-B$ baseline training), a subject can keep on matching the same pair of stimuli even when their respective functional roles are reversed (B-A symmetry). This kind of emergent performance, also named backward association (Gray, 1966; Hogan \& Zentall, 1977) or associative symmetry (Frank \& Wasserman, 2005; Urcuioli, 2008), reveals that related samples and comparisons become mutually substitutable. Furthermore, along with other two emergent performances - matching each stimulus to itself $(A-A$ and $B-B$ identity or reflexivity), and matching two unpaired stimuli that had been related to a third stimulus in common ( $\mathrm{A}-\mathrm{C}$ transitivity, after additional $\mathrm{B}-\mathrm{C}$ training) - emergent symmetry provides behavioral evidence for equivalence-class formation (cf. Sidman et al., 1982; Sidman \& Tailby, 1982).

Untrained conditional discriminations, such as those defining stimulus equivalence have been largely demonstrated in verbally able humans with both typical and atypical development (e.g., Devany et al., 1986; Lazar et al., 1984; Sidman \& Cresson, 1973; Sidman \& Tailby, 1982; Spradlin et al., 1973). However, such a demonstration has proved to be much more difficult with nonverbal subjects (e.g., Devany et al., 1986), especially nonhuman animals (e.g., D’Amato et al., 1985; Hogan \& Zentall, 1977; Lionello-DeNolf \& Urcuioli, 2002; Lipkens et al., 1988; Sidman et al., 1982; Tomonaga et al., 1991; Yamamoto \& Asano, 1995). Only a few studies have reported one kind of emergent performance separately. That is, generalized identity matching has been demonstrated in monkeys (Barros, Galvão, \& Mcllvane, 2002; Oden, Thompson, \& Premack, 1988), pigeons (Zentall, Edwards, Moore, \& Hogan, 1981; Zentall \& Hogan, 1976), sea lions (Kastak \& Schusterman, 1994), dolphins 
(Herman \& Gordon, 1974; Herman, Hovancik, Gory, \& Bradshaw, 1989), and rats (Peña, Pitts, \& Galizio, 2006). Transitivity has been documented in monkeys (Barros, 1998; D’Amato et al., 1985), in a chimpanzee, (Yamamoto \& Asano, 1995), in a sea lion (Schusterman \& Kastak, 1993), and somewhat weaker evidence was found in one of the pigeons that participated in Kuno et al.'s (1994) study. On the other hand, demonstration of symmetry has been widely unsuccessful among nonhuman animals (e.g., Barros, Galvão, \& Fontes, 1996; D’Amato et al., 1985 with monkeys; Dugdale \& Lowe, 2000 with chimpanzees; Gray, 1966; Hogan \& Zentall, 1977; Holmes, 1979; Lionello-DeNolf \& Urcuioli, 2002; Lipkens et al., 1988; Richards, 1988; Rodewald, 1974 with pigeons; Sidman et al., 1982 with monkeys and baboons). This set of results suggests that symmetry may be the critical relation that separates the performance of humans from that of nonhumans in studies on stimulus equivalence (cf. Yamamoto \& Asano, 1995).

This discrepancy concerning results of verbal and nonverbal subjects has led some researchers to reason that demonstration of emergent performances, especially symmetry, may depend on behavioral prerequisites presumably acquired through exposure to training on language competences (Devany et al., 1986; Dugdale \& Lowe, 1990; Hayes, 1989; Hayes et al., 2001, Horne \& Lowe, 1996). On the other hand, it has also been argued that equivalence could constitute the very foundations of language development (Galvão, 1993; Mackay \& Sidman, 1984; Schusterman \& Kastak, 1993; Sidman et al., 1982) and even that it could be a basic behavioral process not reducible to any other (Sidman, $1990 ; 1994 ; 2000)$. In this case, the difficulty in demonstrating equivalence-class formation in nonverbal subjects would have methodological roots, such as inadequate training, inadequate testing or both (cf. Dube, et al., 1993; LionelloDeNolf, 2009).

Although the role of language on equivalence-class formation is so far 
controversial, experimental results have shown that providing a history of reinforced symmetrical relations, an experience that is incidentally embedded on a linguistic training but not restricted to it, seems to encourage the demonstration of a generalized symmetrical responding (as Sidman et al., 1982 had suggested). It has been shown to be the case for both nonhuman animals (e.g., Schusterman \& Kastak, 1993; Yamamoto \& Asano, 1995) and young children who initially fail to show symmetry (e.g., Barnes-Holmes, Barnes-Holmes, Roche, \& Smeets, 2001).

Schusterman and Kastak (1993) provided a sea lion experience with multiple exemplars of samples and comparisons switching their respective functional roles (i.e., symmetry exemplar training) before it could spontaneously demonstrate symmetry with new stimuli. In addition, the sea lion also had previous experience with generalized identity matching with most of the same stimuli (Kastak \& Schusterman, 1994). In both training and testing trials, the sample was presented on a center location with the comparisons on two adjacent side locations. During test sessions, reinforced probes were interspersed among the baseline trials. Only four probes were considered in the analysis of each emergent relation to avoid the direct training of testing performances. For a given relation to be considered emergent, the subject had to respond correctly on the first probe trial and, at least, on two of the remaining three probes of the same relation. After training of many $A-B$ baseline relations, symmetry was tested with six $B-A$ relations and only three emerged. All these six symmetrical relations were then trained to a high accuracy and a novel symmetry test were given with other six B-A relations. Now, the subject passed five tests and, again, all six symmetrical relations were trained to high accuracy levels. Finally, after the sea lion had been trained on additional B-C baseline relations, it passed 10 of 12 C-B symmetry tests.

In addition to training on multiple exemplars of symmetry, Yamamoto and Asano (1995) also trained a chimpanzee to identity relations in order to familiarize it 
with each stimulus in its respective testing location. As samples and comparisons are usually presented on different locations in a MTS task (e.g., samples in a center location and two comparisons in two adjacent side locations), reversing the samplecomparison roles from the baseline training to the symmetry testing causes each stimulus to be presented on a novel location. Such a variation may preclude demonstration of symmetry if the spatial attributes of the stimuli become part of their defining properties (cf. Lionello-DeNolf \& Urcuioli, 2002). In this case, testing relations would not be exactly the symmetrical versions of the baseline relations, because presenting a stimulus on a novel location would create a functionally different stimulus (cf. Iversen, 1997; Iversen, Sidman, \& Carrigan, 1986; Lionello-DeNolf \& Urcuioli, 1998; 2000; Sidman, 1992). Another important issue concerning the sources of stimulus control in testing for symmetry refers to the fact that consistent performance in MTS requires successive discriminations among samples and simultaneous discriminations among comparisons (cf. Saunders \& Green, 1999). Consequently, new discriminations are required during the symmetry testing since stimuli that were previously comparisons become samples and vice-versa. Nevertheless, since each stimulus appears as both sample and comparison during the identity-matching task, it provides all successive and simultaneous discriminations necessary for accurate performance on the symmetry test (as Sidman et al., 1982 had suggested).

Yamamoto and Asano (1995) initially trained the chimpanzee on 18 identity relations (nine $A-A$ and nine $B-B$ ) and then on nine arbitrary relations $(A-B)$. Next, six symmetrical relations $(B-A)$ were gradually tested and then trained, if they were not confirmed (which was the case for all six relations). Unreinforced test probes were inserted among the baseline-arbitrary-relation trials with reduced reinforcement probability. After the training of the first six symmetrical relations, the subject was tested for the remaining three $\mathrm{B}-\mathrm{A}$ relations. On the first session of this test, the 
chimpanzee demonstrated the emergence of two symmetrical relations $(100 \%$ and $83 \%$ correct). However, as test sessions progressed, subject's performance accuracy decreased for both relations. In a subsequent symmetry test with new stimuli (C-B testing, after additional B-C matching), accuracy was once again at chance level.

Although the symmetry and identity training seem to have favored the emergence of two B-A relations, the lack of reinforcement on test trials may explain the loss of stimulus control by both relations from the second test session onwards, and may also explain the chimpanzee's failure to show emergent symmetry with novel stimuli. Compared to the previous training situation, the extinction condition of testing may change considerably the sources of stimulus control, thus preventing the demonstration of emergent relations (cf. Dube \& Mcllvane, 1996; Galvão et al., 1992; Kuno et al., 1994; Schusterman \& Kastak, 1993; Sidman, 1994; Sidman et al., 1982). In addition, the removal of the reinforcement is usually accompanied by resurgent behavior (Villas-Boas et al., 2005, Wilson \& Hayes, 1996), aggression (Azrin et al., 1966), responses of physical attack, urination and defecation (Keller \& Schoenfeld, 1950; Skinner, 1938), as well as increases in behavioral variability (Antonitis, 1951; Lerman \& Iwata, 1996). All of these effects can, in some way, interfere with the demonstration of emergent relations, especially given that unreinforced test trials reproduce the same consequences of incorrect responding during the baseline training.

Lionello-DeNolf and Urcuioli (2002) conducted a study (Experiments 3 and 4) in which exemplar training was carried out and associative symmetry was tested under differential reinforcement conditions. Pigeons were initially trained on A-B matching. In addition, they were also trained on two independent arbitrary-matching tasks (i.e., B-C and $\mathrm{D}-\mathrm{A}$ ) in order to accomplish the same function as the identity matching in the aforementioned study (i.e., to provide the subjects experience with $A$ and $B$ stimuli in both sample and comparison roles, as well as in all locations). To further reduce the 
likelihood that spatial attributes of stimuli became a controlling property of the subjects' performance, samples and comparisons were randomly presented on multiple locations. Since test-trial performance was reinforced, a control group was included to account for possible effects of direct training of tested relations. Thus, following the baseline training, pigeons were divided into two test groups (consistent and inconsistent). For the consistent group, reinforced test relations were the symmetrical versions of the baseline relations (i.e., pecking A1 and A2 comparisons after B1 and B2 samples, respectively, given that subjects had been trained to peck B1 and B2 comparisons after A1 and A2 samples, respectively). For the inconsistent group, reinforced relations were the opposite of the symmetrical versions of the baseline relations (i.e., pecking $\mathrm{A} 1$ and $\mathrm{A} 2$ comparisons after B2 and B1 samples, respectively, given the same baseline training as above). Each pigeon was tested until it matched at high accuracy level on each reinforced relation. Evidence for symmetry would be indicated by first-test-session accuracy well above chance for the consistent group and well below chance for the inconsistent group, as well as by the faster acquisition of the B-A relations by the former group. After reaching the accuracy criterion in this first symmetry test, pigeons were retrained on the additional B-C baseline matching, and were then given a second symmetry test for C-B relations. Finally, after completing this second test, pigeons were retrained on the additional D-A baseline matching and then tested for A-D symmetry. In short, pigeons were first tested and trained on one set of symmetrical relations and then were tested for symmetry with a new set of stimuli. This second set of symmetrical relations was then trained and a new symmetry test was done with a third set of stimuli. Although this sequence of training and testing had provided a history of reinforced symmetrical relations, no evidence of symmetry was found on any of these tests: first-session accuracies were at or close to chance for both consistent and inconsistent groups, and both groups learned the reinforced relations at the same speed. 
Lionello-DeNolf and Urcuioli (2002) reasoned that the relatively limited history of reinforced symmetrical relations (only two sets: $B-A$ and $C-B$ ) may have been insufficient to produce generalized symmetrical responding. Nevertheless, an important methodological issue was not controlled in this study, probably contributing for the pigeon's failure to demonstrate symmetry. Although the pigeons were given experience with the $A$ and $B$ stimuli as both samples and comparisons, by the training of two arbitrary matching (B-C and $\mathrm{D}-\mathrm{A})$ in addition to the initial $\mathrm{A}-\mathrm{B}$ matching, the same was not true for the $C$ and $D$ stimuli. In other words, before the second $(C-B)$ and third $(A-D)$ symmetry tests, respectively, pigeons had never learned to discriminate among the C stimuli successively and the D stimuli simultaneously.

The present study was designed to test whether pigeons can show emergent associative symmetry after they have experienced a relatively short history of reinforced symmetrical relations in a training procedure that provided all prerequisite successive and simultaneous discriminations among the testing stimuli. In a twoalternative MTS procedure, pigeons were initially trained on two independent arbitrarymatching tasks ( $A-B$ and $C-D)$ involving two stimulus sets (Set 1 and Set 2). Then, a reinforced symmetry test was conducted with Set-1 stimuli (B1-A1 and D1-C1). To control for the effects of reinforcement during test trials, two novel relations (not inconsistent) were concurrently reinforced by recombining stimuli from the Set-2 baseline relations (D2-A2 and B2-C2). If symmetry emerges, then first-test-session accuracies should be above chance on the symmetrical relations and at chance on the novel relations. Somewhat weaker evidence of symmetry would be indicated if pigeons learned the symmetrical relations faster than the novel relations over repeated test sessions. Once pigeons learned all reinforced testing relations to high accuracy levels, they also learned to discriminate $B$ and $D$ stimuli successively, as well as A and C stimuli simultaneously. Afterwards, pigeons were retrained in the original baseline 
relations and were then given a second symmetry test for Set-2 relations (B2-A2 and D2-C2), with Set-1 stimuli being now recombined to form two novel relations used as experimental control (D1-A1 and B1-C1). Since the first reinforced symmetry test had provided experience with samples and comparisons switching roles, as well as all prerequisite discriminations among current samples and comparisons, one should expect that pigeons would show stronger evidence for associative symmetry in this second test. 


\section{METHOD}

Subjects

The subjects were four pigeons (P1, P2, P3 and P4) that had been used in a previous experiment on temporal discrimination. Each pigeon was individually housed in a stainless-steel cage and had free access to water and grit when not in the experimental chamber. A 13/11-h light/dark cycle was in effect in the pigeon colony with lights on at 8:00. Throughout the experiment, the pigeons were maintained at $80 \%$ of their free-feeding body weights by restricting feeding to the experimental sessions.

\section{Apparatus}

Two custom-built operant conditioning chambers constructed of brushed aluminum, and measuring $37 \times 45 \times 44-\mathrm{cm}$ were used. The front wall of each chamber was equipped with a 15-inch touchscreen LCD monitor (Elo Touch 1515L) that required approximately $100-\mathrm{g}$ to be activated. A pair of speakers located behind each monitor emitted a sound of "click" every time the touchscreen was activated. An opaque Plexiglas plate, measuring $30 \times 6-\mathrm{cm}$, covered the lower portion of the touchscreen making available to the subject only an area of $30 \times 17-\mathrm{cm}$.

Visual stimuli were displayed individually or in pairs, on three possible locations of the screen (left, center and right). The three stimulus locations were spaced $6-\mathrm{cm}$ apart, center-to-center, and were horizontally aligned in a row $24-\mathrm{cm}$ from the floor of the chamber. Each location corresponded to an area of $5-\mathrm{cm}^{2}$ into which pecks with force superior than 100-g activated the screen, and produced the outcomes specifically programmed to each experimental condition (see procedure below). Pecking outside the stimulus location or inside an empty location had no programmed consequences. 
The background of the screen remained black across the experiment and nine visual stimuli were presented in different conditions. A $4 \times 4-\mathrm{cm}$ white square was used only in the preliminary training. Eight black irregular forms superimposed on a $4 \times 4-\mathrm{cm}$ white square were used both in the preliminary training and in all subsequent experimental phases (see procedure below). These stimuli were randomly divided into two four-stimulus sets (Figure 2.1). Stimuli component of Set 1 and Set 2 were counterbalanced across subjects.

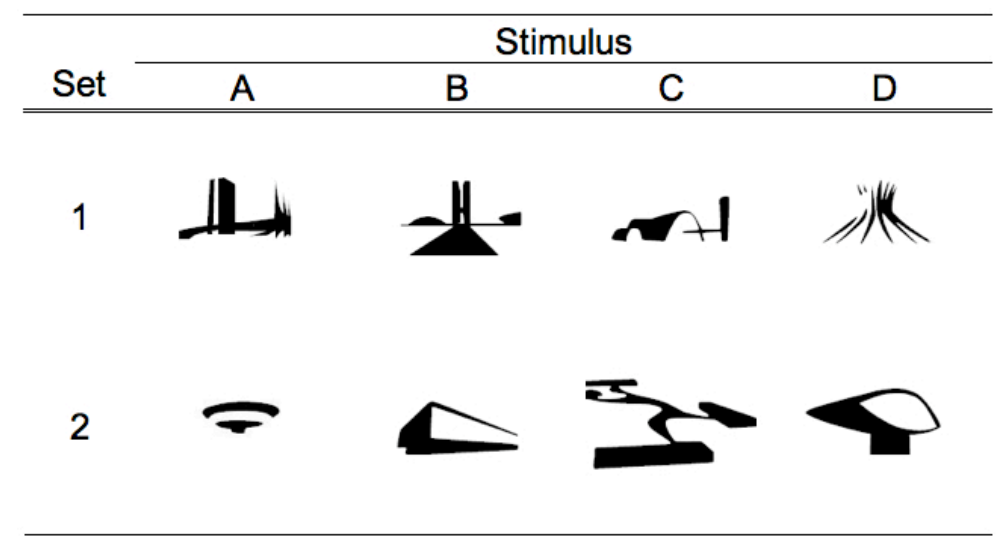

Figure 2.1. Graphic representation of the eight stimuli used in all experimental phases of the Study 2. Only sample-comparison relations among stimuli of the same set were reinforced.

A food hopper was accessible through an opening $(6 \times 5,5-\mathrm{cm})$ centered on the rear wall of the chamber, $8-\mathrm{cm}$ above the floor. When activated, the food hopper was illuminated with a 7.5-W white light and allowed access to mixed grain. Another 7.5-W white light (houselight) located 16,5-cm above the food hopper opening provided general illumination. A blower fan mounted on the sidewall of the chamber provided ventilation and masking noise. A digital interface (Keithley/KPCI-PDISO8) connected 
each chamber to a computer. All experimental events were controlled and recorded by software developed in Visual Basic (Pigeon 1311).

\section{Procedure}

Preliminary training. Subjects were trained to eat immediately and consistently from the food hopper whenever it was activated at irregular intervals. Each pigeon was then trained by the method of successive approximations to peck the white square at the center location until 50 reinforcers were given (i.e., 50 food presentations contingent upon 50 pecks on the white square). A single 96-trial session was conducted in which the white square appeared equally often in each of the three locations randomly sorted. In subsequent 96-trial sessions, the eight irregular forms (Figure 2.1) appeared randomly and equally often in each of the three location. The order of stimulus presentation was randomized in successive blocks of eight trials. Daily sessions were conducted until response latencies to each stimulus on each location averaged 2-s or less. In all above described conditions, a single peck to the presented stimulus (i.e., fixed-ratio 1 or FR 1 ) turned it off and immediately produced 3$s$ access to the raised food hopper.

Next, the FR requirement for pecking the stimulus presented at the center location — which would later serve as the sample location in MTS task (see below) was gradually raised to 10 over the course of $6-9$ sessions. Each FR training session comprised 96 trials in which the eight irregular forms (Figure 2.1) appeared equally often and randomly on the center location. The food hopper was raised contingent upon three pecks (FR 3) during the first session, five pecks (FR 5) during the second session, seven pecks (FR 7) during the third session, and ten pecks (FR 10) during the remaining three sessions for subjects $\mathrm{P} 2, \mathrm{P} 3$ and $\mathrm{P} 4$ and six sessions for $\mathrm{P} 1$. FR 10 sessions lasted until the time to complete the response requirement averaged 10 -s or 
less in a session. During all FR sessions, the duration of the food hopper activation was constant within a particular session, but varied between 2 and $4 \mathrm{~s}$ across sessions in order to maintain each pigeon as close as possible to its $80 \%$ free-feeding weight.

During the preliminary training, each successive stimulus presentation was separated by a 10-s intertrial interval (ITI) initiated at once the food hopper closedown. The houselight was on during the initial 9-s of the ITI, but it was turned off for the last 1$\mathrm{s}$ and remained off until the onset of the next ITI.

Matching-to-sample task. A 0-s delay arbitrary MTS procedure was used in the subsequent 96-trial sessions. Each matching trial began with the onset of the sample stimulus in the center location. Pecking the sample ten times (FR 10) turned it off and immediately produced the presentation of two comparisons in the adjacent side locations (left and right). A single peck (FR 1) to the comparison arbitrarily set as the correct $(\mathrm{S}+)$ terminated both stimuli, activated the food hopper, and after its closedown initiated a 10-s ITI with the same light/dark circle described for the preliminary training (this was recorded as a correct choice). Pecking the comparison arbitrarily set as the incorrect (S-) produced the same consequences except for the non-activation of the food hopper (this was recorded as an incorrect choice). The duration of each food hopper activation was constant within a particular session, but varied between 2 and 4 $s$ across sessions in order maintain each pigeon's weight as close to $80 \%$ as possible.

Baseline training. With the procedure just described, subjects were trained to match $A 1$ and $A 2$ samples to $B 1$ and $B 2$ comparisons, respectively, as well as they were trained to match $\mathrm{C} 1$ and $\mathrm{C} 2$ samples to $\mathrm{D} 1$ and $\mathrm{D} 2$ comparisons, respectively. The four possible combinations involving each sample and its correct $(\mathrm{S}+)$ and 
incorrect (S-) comparisons are shown in the left panel of Table 2.1. In training of each sample-comparison relation, the corresponding $S+$ and $S-$ appeared equally often on both left and right locations. The eight resulting trial types were equally probable in each 96-trial session and were randomized in blocks of eight trials to ensure a uniform distribution of all possible trial types throughout a session. The only constraints on trial order were that a particular sample could not appear more than twice in succession, and that a particular location could not contain an $\mathrm{S}+$ on more than three trials in a row.

Table 2.1. Alphanumeric representation of the trial types presented to the pigeons in each experimental condition of the Study 2.

\begin{tabular}{|c|c|c|c|c|c|}
\hline \multicolumn{2}{|c|}{ Baseline training } & \multicolumn{2}{|c|}{ Symmetry test 1} & \multicolumn{2}{|c|}{ Symmetry test 2} \\
\hline Set 1 & Set 2 & Symmetrical & Novel & Symmetrical & Novel \\
\hline A1-B1 B2 & A2-B2 B1 & $\mathrm{B} 1-\mathrm{A} 1 \mathrm{~A} 2$ & D2-A2 A1 & $\mathrm{B} 2-\mathrm{A} 2 \mathrm{~A} 1$ & $\mathrm{D} 1-\mathrm{A} 1 \mathrm{~A} 2$ \\
\hline C1-D1 D2 & C2-D2 D1 & D1-C1 C2 & $\mathrm{B} 2-\mathrm{C} 2 \mathrm{C} 1$ & $\mathrm{D} 2-\mathrm{C} 2 \mathrm{C} 1$ & $\mathrm{~B} 1-\mathrm{C} 1 \mathrm{C} 2$ \\
\hline
\end{tabular}

Note - The first alphanumeric element represents the sample, the second represents the "correct" comparison ( $\left.\mathrm{S}^{+}\right)$and the third represents the "incorrect" comparison (S-).

During the baseline training, incorrect choices caused the trial to be repeated after the ITI (correction procedure) up to a maximum of three trials or until a correct choice was made (whichever occurred first). On the trial following the third repetition, only the $\mathrm{S}+$ was presented. Thus, the total number of trials on a particular training session were the sum of 96 programmed trials and all the correction trials. Only the choice made on the first exposure to a given trial was scored as a correct or incorrect response (i.e. correction trials were not included). Each pigeon received one training session daily until it matched correctly on $90 \%$ or more of the 96 programmed trials for two consecutive sessions, and with no more than four incorrect responses on a particular relation. Two pigeons (P2 and P4) showed few signs of acquisition after 50 
sessions so a 15-s timeout period was introduced after each incorrect choice from the following session onwards. During the timeout period both the houselight and the screen reminded off. After reaching the accuracy criterion, each subject was overtrained for 20 sessions without the correction procedure.

Symmetry test 1 . On the day following the last overtraining session, subjects were tested for symmetry with samples from the baseline being used as comparisons, and vice-versa. Test performances were differentially reinforced over the course of 96trial sessions. On half of the trials, reinforced sample-comparison relations were the symmetrical versions of half of baseline relations (i.e., pecking A1 comparison after B1 sample, as well as pecking C1 comparison after D1 sample, given that the reversal relations had been reinforced in the baseline training). In order to control for the effects of reinforcement of the symmetrical relations, two novel relations were reinforced on the remaining trials by recombining stimuli from the remaining baseline relations (i.e., pecking A2 comparison after D2 sample, as well as pecking C2 comparison after B2 sample, given that subjects had been trained to match D2 comparison to C2 sample and B2 comparisons to A2 sample). Symmetrical and novel relations were concurrently reinforced for each subject. The four possible combinations involving each test sample and its corresponding $S+$ and $S$ - are shown in the center panel of Table 2.1. All procedural details were identical to those described for the baseline training, except that incorrect choices were not followed by either the correction procedure or the timeout period. Similar to baseline training, testing sessions were conducted daily with each pigeon until its overall accuracy was $90 \%$ correct or higher for two consecutive sessions with no more than four incorrect choices concentrated on a particular relation.

Baseline retraining. After completing the symmetry test 1 , all pigeons were 
retrained on the original baseline relations (left panel of Table 2.1). All procedural details were identical to those employed during the original training excepting that the correction procedure and the timeout period were no more in use. The performance criterion was also the same.

Symmetry test 2. Following the last baseline retraining session, each pigeon was given a new symmetry testing which was procedurally identical to the first one. Only the reinforced sample-comparison relations were different from those of the first symmetry test. Once pigeons had been previously tested on the symmetrical versions of Set-1 baseline relations, then they were tested for symmetry with Set-2 baseline relations (i.e., B2-A2 and D2-C2). Similarly, once the earlier novel relations had been formed by recombining stimuli from the Set-2 baseline relations, then, in this second test, the novel relations comprised the recombination of the Set-1 baseline stimuli (i.e., $\mathrm{D} 1-\mathrm{A} 1$ and $\mathrm{B} 1-\mathrm{C} 1)$. The four possible combinations involving each testing sample and its corresponding $\mathrm{S}_{+}$and $\mathrm{S}-$ are shown in the right panel of Table 2.1. This second symmetry test consisted of a single 96-trial session. 


\section{RESULTS}

Baseline training. Pigeons P1, P2, P3 e P4 required a total of 25, 79, 55 and 69 sessions, respectively, to acquired the baseline relations to a criterion of $90 \%$ accuracy or better with no more than four errors in each particular relation on the criterion session. Acquisition of baseline relations trained with Set-1 stimuli was compared with the acquisition of those trained with Set-2 stimuli, and no significant difference was found with respect to the number of sessions required for pigeons to reach the performance criterion on both groups of relations $(Z=-.368, p=.713)$. The mean number of sessions to reach the specified criterion was 50 for Set-1 and 49 for Set-2 relations.

Figure 2.2 shows matching accuracy by individual subjects over five-session blocks of the baseline training, when the reinforced training relations were composed of either Set-1 or Set-2 stimuli. All the pigeons performed at the chance level on both Set1- and Set-2-relation trials during the first five-session block. Performance accuracy on Set-1 and Set-2 relations improved together across five five-session blocks for P1. Whereas for P2, P3 and P4, accuracies fluctuated slightly with respect to both Set-1 and Set-2 relations, gradually increasing across 18, 12, 13 five-session blocks, respectively. Accuracies on Set-1- and Set-2-relation trials did not differ significantly from one another across training sessions for all the pigeons $(Z=-1.058, p=.290)$.

Such a result provided an important experimental control for the reinforced symmetry test since the symmetrical and the novel relations were drawn from different sets of stimuli: when the symmetrical relations were formed with Set-1 stimuli, the novel relations were formed with Set-2 stimuli, and vice-versa. To the extent that there was no significant difference between the acquisition of Set-1 and Set-2 relations, possible higher accuracies on the symmetrical-relation than on the novel-relation trials would 
indicate associative symmetry rather than unknown controls, such as inherent stimulus properties.

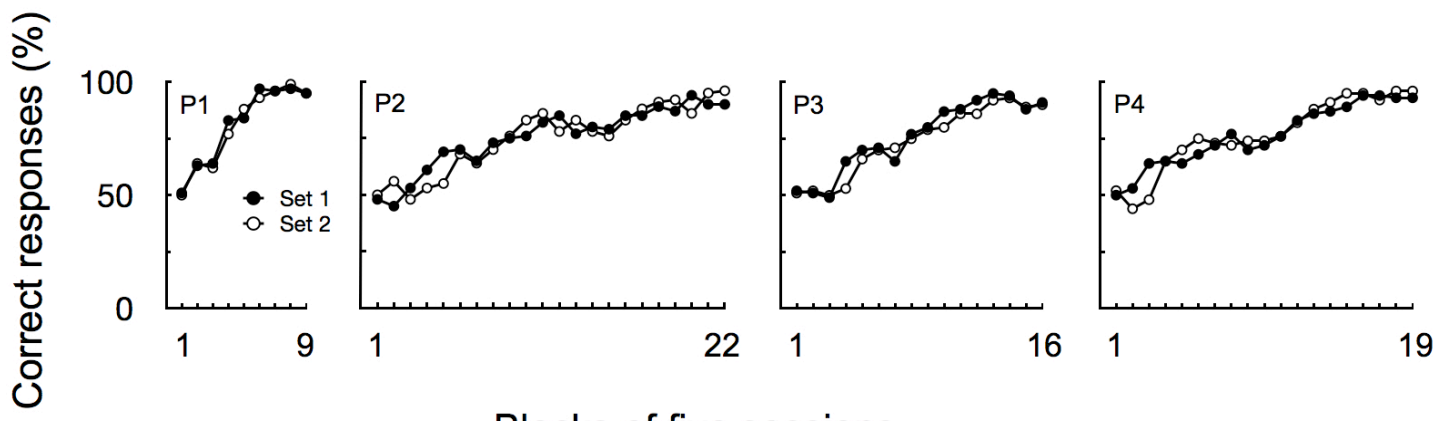

Blocks of five sessions

Figure 2.2. Matching accuracy for individual pigeons over five-session blocks of baseline training of the Study 2. The reinforced relations consisted of either Set-1 (solid circles) or Set-2 stimuli (open circles). The last four five-session blocks of each subject refer to the overtraining sessions. The number of sessions in the last session block preceding the overtraining was six for Pigeons $\mathrm{P} 1$ and $\mathrm{P} 3$, three for $\mathrm{P} 2$ and two for $\mathrm{P} 4$.

In order to carryout an analysis of responding location bias, sessions in which a particular comparison location (right or left) was chosen in more than $70 \%$ of the trials were recorded as a positional-response session, and its total number was summed for each pigeon (2, 17 and 7 for P1, P3 and P4, respectively). Given the large number of sessions in which P3 showed a position bias, a laterality correction procedure was used for this subject: the average of right and left choices was calculated for the last five sessions and, for the following session, the probability that an $S+$ be presented in the preferred location was reduced proportionally to the inverse of the mean of the preference. For example, if during the last five sessions the right location was chosen in $75 \%$ of the trials in average, then, in the following session, the probability of an S+ be presented in that location decreased from 0.5 to 0.25 (i.e., the $S+$ 's were presented 
in the opposite location on $75 \%$ of the trials). This correction procedure was used until the mean of the location preference - updated with respect to current last five sessions - became less than $60 \%$, and was reintroduced every time the location bias reached the $70 \%$ criterion again. The total number of sessions in which the laterality correction procedure was used for P3 was 12 .

Accuracies on baseline trials remained high for all pigeons during the overtraining. In the last two overtraining sessions that immediately preceded the first symmetry test session, the individual performance accuracies averaged 94\%, 93\%, 91\% and $95 \%$ for Subjects P1, P2, P3 and P4, respectively.

Symmetry test 1. Figure 2.3 shows individual first-session performance accuracies when the reinforced test relations were either symmetrical versions of the baseline relations or novel combinations of baseline stimuli. The predictions, in line with symmetry, were that pigeons should perform above-chance levels of accuracy on the symmetrical-relation and at chance level on the novel-relation trials. Indeed, accuracies on symmetrical-relation were higher than on novel-relation trials for two pigeons ( $\mathrm{P} 1$ and P2), but the percentages of correct choices were only at chance on the former ( $51 \%$ and $54 \%$, respectively) and below chance on the latter (38\% e $40 \%$, respectively). First-session performances on the symmetrical relations were not significantly more accurate than on the novel relations for such subjects $(Z=-1.342 ; p$ $=.180)$. For the remaining two pigeons ( $\mathrm{P} 3$ and $\mathrm{P} 4)$ accuracy was at chance level in the novel-relation $(56 \%$ and $54 \%$, respectively) but only below chance in the symmetrical-relation trials $(35 \%$ and $31 \%$, respectively). Thus, no evidence of symmetry was found in this first test session. 


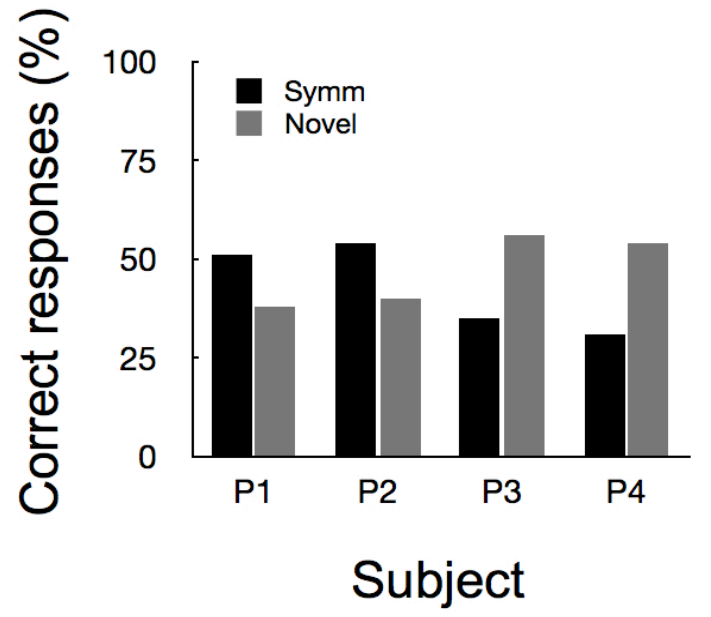

Figure 2.3. Matching accuracy on the first session of the symmetry test 1 by individual pigeons of the Study 2. The reinforced relations were either symmetrical versions of Set-1 baseline relations (black bars) or novel recombination of Set-2 baseline stimuli (gray bars).

Figure 2.4 shows individual matching accuracy averaged across five-session blocks of the symmetry test, when the reinforced test relations were symmetrical versions of the baseline relations or novel combinations among baseline stimuli. Pigeon P1 performed above-chance level on the symmetrical-relation trials $(63 \%$ correct), and below-chance level on the novel-relation trials $(40 \%$ correct) in the first five-session blocks. In contrast, performances on both symmetrical- and novel-relation trials were at, around or slightly above chance for Pigeons P2, P3 and P4, respectively. Accuracies for P2 and P3 fluctuated across blocks of five sessions on both symmetrical and novel relations, improving gradually across 50 and 60 sessions, respectively. Accuracies for P1 and P4 improved across 30 sessions with less fluctuation. Contrary to predictions, there was no significant difference between matching accuracies on symmetrical- and novel-relation trials throughout test sessions $(Z=-.280, p=.779)$. Furthermore, the symmetrical relations were not acquired any more quickly than the 
novel relations $(Z=-.365, p=.715)$.

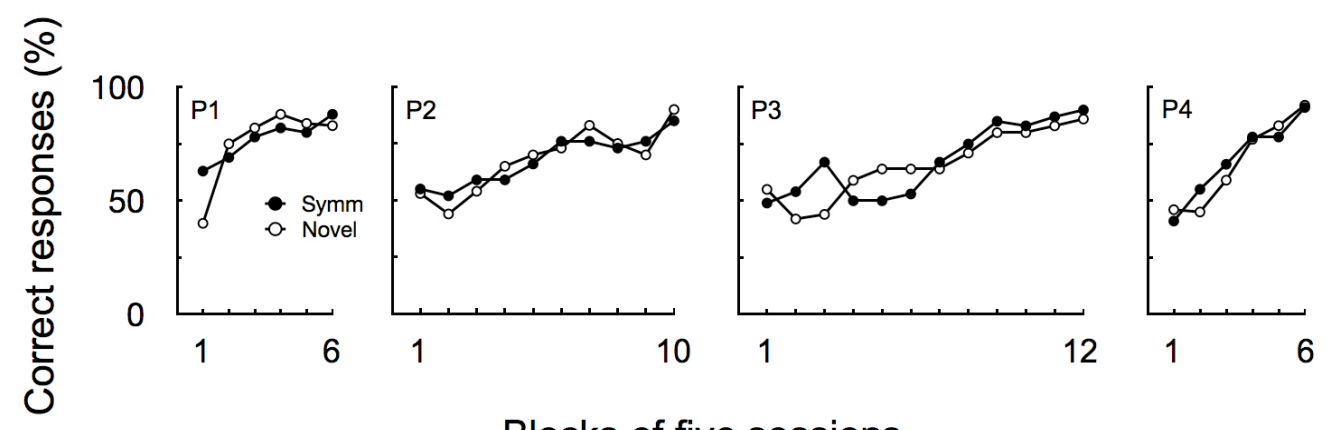

Blocks of five sessions

Figure 2.4. Matching accuracy for individual pigeons across five-session blocks in the symmetry test 1 of the Study 2. The reinforced relations were either symmetrical versions of baseline relations (solid circles) or novel recombination of baseline stimuli (open circles). The number of sessions in the last session block was three for Pigeon P3 and two for P4.

Baseline retraining. Subjects P1, P2, P3 e P4 required 4, 10, 13 and 14 sessions, respectively, to reestablish the accuracy criterion on the baseline relations. Individual matching accuracy on the last two baseline retraining session preceding the second testing averaged $95 \%, 94 \%, 99 \%$ and $90 \%$ for Set- 1 relations and $100 \%, 91 \%$, $96 \%$ and $94 \%$ for Set-2 relations, respectively.

Symmetry test 2. Figure 2.5 shows percentage of correct responses on the first session of the second symmetry test when the reinforced relations were either symmetrical or novel concerning the baseline relations. All pigeons performed well above chance-level on the symmetrical-relation trials (range $69 \%$ to $77 \%$ ). In contrast, 
on the novel-relation trials, P4 and P1 matched close (52\%) and slightly above chance (60\%), respectively, while P2 and P3 matched well below chance-level (21\% and 35\%). A Binomial test, based on the individual difference in the proportion of correct responses on symmetrical- and novel-relation trials showed high levels of significance for Pigeons P2 $(Z=5.513, p<.001), P 3(Z=3.477, p<.001)$ and $P 4(Z=1.887, p=$ $.037)$.

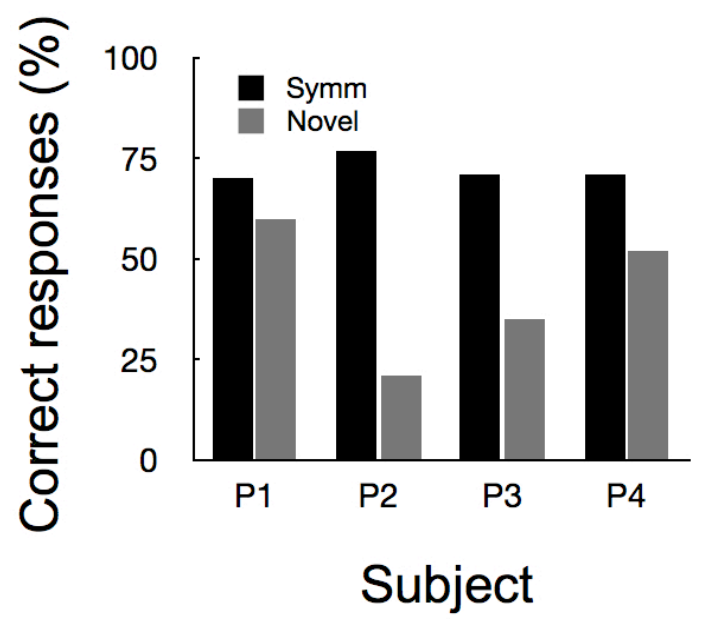

Figure 2.5. Matching accuracy on the first session of the symmetry test 2 by individual pigeons of the Study 2. The reinforced relations were either symmetrical versions of Set-2 baseline relations (black bars) or novel recombination of Set-1 baseline stimuli (gray bars).

Table 2.2 shows individual performances on the first four trials of each symmetrical and novel relation in the symmetry test 2 . Strong evidence of symmetry was found considering the emergence criteria used by Schusterman and Kastak (1993) - a correct choice on the first test trial and, at least, on two of the remaining three trials. All pigeons met this emergence criterion on every symmetrical relations but only one pigeon (P4) did so on a single novel relation. 
Table 2.2. Performance of individual pigeons in the first four trials of each reinforced relation in the symmetry test 2 of the Study 2 . The reinforced relations were either symmetrical versions of training relations or novel recombination of training stimuli. (O) indicates a correct response; $(X)$ indicate an incorrect response.

\begin{tabular}{|c|c|c|c|c|c|c|}
\hline \multirow{3}{*}{$\frac{\text { Subject }}{\mathrm{P} 1}$} & \multirow{2}{*}{\multicolumn{2}{|c|}{ Relation }} & \multicolumn{4}{|c|}{ Trial } \\
\hline & & & \multirow{2}{*}{1} & \multirow{2}{*}{$\frac{2}{0}$} & \multirow[b]{2}{*}{$\mathrm{O}$} & \multirow[b]{2}{*}{ O } \\
\hline & \multirow[t]{2}{*}{ Symm } & B2-A2 & & & & \\
\hline & & D2-C2 & $\mathrm{O}$ & $\mathrm{O}$ & X & $\mathrm{O}$ \\
\hline & \multirow[t]{2}{*}{ Novel } & B1-C1 & $X$ & $\mathrm{O}$ & $X$ & $\mathrm{O}$ \\
\hline & & D1-A1 & $X$ & $X$ & $\mathrm{O}$ & $X$ \\
\hline \multirow[t]{4}{*}{ P2 } & \multirow[t]{2}{*}{ Symm } & B2-A2 & $\mathrm{O}$ & $\mathrm{O}$ & $X$ & $\mathrm{O}$ \\
\hline & & D2-C2 & $\mathrm{O}$ & $\mathrm{O}$ & $\mathrm{O}$ & $\mathrm{O}$ \\
\hline & \multirow[t]{2}{*}{ Novel } & B1-C1 & $\mathrm{O}$ & $X$ & $X$ & $\mathrm{X}$ \\
\hline & & D1-A1 & $x$ & $X$ & $\mathrm{O}$ & $X$ \\
\hline \multirow{4}{*}{ P3 } & \multirow{2}{*}{ Symm } & B2-A2 & $\mathrm{O}$ & X & $\mathrm{O}$ & $\mathrm{O}$ \\
\hline & & D2-C2 & $\mathrm{O}$ & X & $\mathrm{O}$ & $\mathrm{O}$ \\
\hline & \multirow[t]{2}{*}{ Novel } & B1-C1 & $\mathrm{X}$ & $X$ & $X$ & $X$ \\
\hline & & D1-A1 & $X$ & $\mathrm{O}$ & $X$ & $X$ \\
\hline \multirow[t]{4}{*}{ P4 } & \multirow[t]{2}{*}{ Symm } & B2-A2 & $\mathrm{O}$ & $X$ & $\mathrm{O}$ & 0 \\
\hline & & D2-C2 & $\mathrm{O}$ & $\mathrm{X}$ & $\mathrm{O}$ & $\mathrm{O}$ \\
\hline & \multirow[t]{2}{*}{ Novel } & B1-C1 & $\mathrm{X}$ & $\mathrm{O}$ & $\mathrm{O}$ & O \\
\hline & & D1-A1 & $\mathrm{O}$ & $X$ & $\mathrm{O}$ & $\mathrm{O}$ \\
\hline
\end{tabular}




\section{DISCUSSION}

The results indicate that pigeons can show a generalized symmetrical responding after a sequence of training and testing in which exemplars of symmetry were provided along with the prerequisite discriminations among test samples and comparisons. After pigeons had learned two arbitrary-matching tasks ( $A-B$ and $C-D)$, they were given a reinforced symmetry test for half of the baseline relations (B1-A1 and D1-C1). In order to control for the effects of reinforcement on test trials, two novel relations were concurrently reinforced using familiar stimuli from the remaining baseline relations (D2-A2 and B2-C2). Once pigeons matched at or close to chance on both symmetrical- and novel-relation trials (i.e., symmetry was not observed), such relations were trained to high accuracy levels, thus providing successive and simultaneous discriminations among samples and comparisons of the next symmetry test, respectively. Then, in the first session of the second test, pigeons performed more accurately on the remaining, untrained symmetrical relations (B2-A2 and D2-C2) than on two additional novel relations (D1-A1 and $B 1-C 1)$. The result of this first test session was not as robust as those of verbally able humans (e.g., Lazar et al., 1984; Sidman \& Cresson, 1973; Sidman \& Tailby, 1982; Spradlin, et al., 1973) but was consistent across subjects. Nonetheless, strong evidence of emergent symmetry was found considering only the first four test trials. All pigeons responded correctly in the first trial of each symmetrical relation and, at least, on two of the subsequent three trials (Schusterman and Kastak's emergence criterion). In contrast, only two pigeons (P2 and P4) made a correct response on the first trial of a single novel relation, and only one of them (P4) responded correctly on two of the next three trials. In short, pigeons did not show any evidence of symmetry in the first test but after two symmetrical relations were explicitly trained, associative symmetry emerged in a second test with 
new relations.

This result sharply contrasts with the lack of symmetry reported in most nonhuman animal studies (e.g., Barros et al., 1996; D'Amato et al., 1985; Dugdale \& Lowe, 2000; Gray, 1966; Hogan \& Zentall, 1977; Holmes, 1979; Lionello-DeNolf \& Urcuioli, 2002; Lipkens et al., 1988; Richards, 1988; Rodewald, 1974; Sidman et al., 1982). Especially interesting is the discrepancy between our results and those reported by Lionello-DeNolf and Urcuioli (2002). In both studies, pigeons were given symmetry exemplar training and were tested for emergent symmetrical responding under differential reinforcement conditions (two variables identified as important for demonstration of symmetry in nonhuman animals). Nevertheless, unlike our pigeons, Lionello-DeNolf and Urcuioli's subjects had not learned all prerequisite discriminations among the stimuli used in the critical symmetry test. In that study, pigeons were trained on three arbitrary-matching tasks $(\mathrm{A}-\mathrm{B}, \mathrm{B}-\mathrm{C}$ and $\mathrm{D}-\mathrm{A})$ during which $\mathrm{A}$ and $\mathrm{B}$ stimuli appeared as both samples and comparisons. Next, B-A symmetry was tested and, since it was not observed, B-A matching was trained to high accuracy levels. Afterwards, C-B symmetry was first tested and then trained before A-D symmetry testing. Despite this prior history of reinforced symmetrical relations, pigeons matched at chance in both C-B and A-D tests. It is important to note that before such tests pigeons had never learned to discriminate among $C$ stimuli as samples and D stimuli as comparisons, respectively. In other words, symmetry may have not emerged simply because subjects lacked the prerequisite discriminative repertoire for that.

In our experiment, by contrast, all prerequisite discriminations seemed to be provided by reinforcing the symmetrical and novel relations to high accuracy levels over the course of the first symmetry test. The strategy of using novel relations as experimental control for the reinforced symmetry test (rather than inconsistent relations) allowed symmetry to be repeatedly tested using the same baseline stimuli. Thus once 
the stimuli that first integrated the symmetrical relations were later recombined to form novel relations, and vice-versa, the first reinforced symmetry test provided all prerequisite discriminations for the next test. In other words, at the onset of the second symmetry test, pigeons already had experience with the current samples and comparisons in their respective roles and locations.

Another important advantage of this procedure is that both symmetrical and novel relations can be concurrently reinforced for the same subject (i.e., single-subject design). The use of inconsistent relations, in turn, would confound the interpretation of results in single-subject designs. The reinforcement of inconsistent relations (e.g., A1-B2 and A2B1) concurrently to the symmetrical relations (e.g., A1-B1 and A2-B2) would merge the stimuli into a single large class (e.g., A1A2B1B2C1C2) thus resulting in chance-level performances in both sets of relations.

Our results, on the other hand, join those of Schusterman and Kastak (1993) with a sea lion, and those of Yamamoto and Asano (1995) with a chimpanzee in showing emergent symmetrical responding after symmetry exemplar training. Notably, both the sea lion and the chimpanzee were also trained on identity-matching tasks which provided them experience with each stimulus in both sample and comparison roles. Thus, just as in the present study, their subjects learned in advance all successive and simultaneous discriminations necessary for accurate performance in the symmetry test, and were also familiarized with each stimulus on its respective testing location.

A noteworthy question however concerns the very limited number of exemplar training required before our pigeons demonstrated an emergent symmetrical responding. Whereas Schusterman and Kastak's (1993) sea lion was trained in six symmetrical relations before showing emergent symmetry, only two symmetrical relations were trained before our pigeons showed this same kind of emergent performance. In contrast, Yamamoto and Asano (1995) reported only transitory evidence of emergent symmetry 
after their chimpanzee was trained in six symmetrical relations. Afterwards, no evidence was found in a subsequent test with new stimuli (it is likely, however, that test performance was under extinction due to the lack of reinforcement on test trials). The limited number of exemplar training carried out in our study might lead to the conclusion that generalized symmetrical responding already existed in the pigeons' repertoire. In that sense, the exemplar training provided over the course of the first symmetry test would have served only to establish the prerequisite discriminations required for the subsequent demonstration of emergent symmetry, as well as to set the experimental context for such emergence. Although this hypotheses needs to be systematically checked, it can be partially supported by two studies that succeeded in showing associative symmetry in pigeons in the absence of explicit exemplar training.

In one such study, Frank and Wasserman (2005) reported the strongest evidence to date for emergent symmetry in pigeons. They used a successive MTS procedure in which sample and comparison appeared individually one after another in a single location to prevent spatial dimensions from gaining control over subjects' responses. To control for temporal location cues, two identity-matching tasks ( $A-A$ and B-B) were concurrently trained interspersed with the target arbitrary-matching task (A-B) so that during training each stimulus appeared as both the first (sample) and the second (comparison) stimulus. Half of the trials consisted of sample-comparison relations during which pecks to the comparison stimulus were reinforced (e.g., A1-B1 and A2-B2). The remaining half of the trials consisted of sample-comparison relations during which pecks to the comparison were extinguished (e.g., A1-B2 and A2-B1). Pigeons were trained until a discrimination ratio of 0.80 in a session was reached. Afterwards, symmetrytesting sessions were conducted in which arbitrary and identity-matching trials were intermixed with symmetry testing trials $(B-A)$ that involved the reversal of the arbitrary training relations. Even with no reinforcement in symmetry testing trials, pigeons pecked 
much more on the reverse of the reinforced arbitrary relations (B1-A1 and B2-A2) than on the reverse of the nonreinforced arbitrary relations (B1-A2 and B2-A1), a clear evidence of emergent symmetrical responding. Similar results, although less robust, were reported in a replication conducted by Urcuioli (2008) also with pigeons.

However, although these pigeons clearly lacked an experimental history of reinforced symmetrical relations before the test, it is worthy mentioning that they had an incidental experience with nonreinforced symmetrical relations. During the identitymatching task, pecking the A2 comparison was extinguished after the A1 sample, as well as pecking the $A 1$ comparison was extinguished after the $A 2$ sample (A1-A2 and A2A1). Likewise, pecking the B2 and B1 comparisons was extinguished after either the B1 or B2 samples, respectively (B1-B2 and B2-B1). In other words, subjects were given a training procedure in which responding to pairs of symmetrical relations produced the same programmed outcome (i.e., extinction). Whether or not this history of nonreinforced symmetrical relations may have facilitated the subsequent demonstration of an emergent symmetrical responding is an experimental question that is being systematically investigated by Rico (2009) in an ongoing study.

To conclude, the present study showed that associative symmetry can emerge in nonhuman animals under adequate conditions of training and testing. Although explicit reinforcement of symmetrical relations has been considered the most critical condition in order to bring about the emergence of symmetry (cf. Schusterman \& Kastak, 1993; Sidman et al., 1982), such a procedure does not seem sufficient (see Lionello-DeNolf \& Urcuioli, 2002; Yamamoto \& Asano, 1995). It is also necessary to provide the subjects appropriate discriminations among test samples and comparisons, as well as prior experience with each stimulus in its corresponding test location. Furthermore, reinforced test trials seem to encourage demonstration of emergent symmetrical responding in nonhuman animals. When all these aforementioned conditions were met, our experiment 
succeeded in providing the first evidence of associative symmetry by pigeons in a twoalternative MTS procedure. 


\section{CONSIDERAÇÕES FINAIS}

Os dois estudos aqui descritos confirmam a possibilidade de se avaliar relações condicionais que atestam as propriedades da equivalência em condições exclusivas de reforçamento, estratégia essa de grande valor quando se trata da investigação envolvendo sujeitos não-humanos e humanos com desenvolvimento atípico. Em linha gerais, o procedimento envolve a comparação dos desempenhos de um mesmo sujeito durante tentativas de teste em que são reforçadas tanto relações consistentes com a formação de classes de equivalência (e.g., simétricas e transitivas) quanto relações inéditas formadas pela recombinação de estímulos familiares da linha de base. No que se refere aos resultados obtidos, os participantes humanos (Estudo 1) responderam com acurácia superior nas relações simétricas e transitivas no decorrer de todo o teste, corroborando, assim, os resultados de estudos anteriores que empregaram o paradigma tradicional de equivalência em sujeitos verbalmente competentes (e.g., Devany, et al., 1986; Lazar et al., 1984; Sidman \& Cresson, 1973; Sidman \& Tailby, 1982; Spradlin et al., 1973). Os pombos (Estudo 2), por sua vez, desempenharam ao nível do acaso tanto nas relações simétricas quanto nas relações inéditas em um primeiro teste envolvendo a metade dos estímulos da linha de base. Porém, depois que tais relações (simétricas e inéditas) foram treinadas até alto grau de acurácia, todos os pombos responderam com precisão superior nas relações simétricas de um segundo teste envolvendo os estímulos restantes da linha de base. Esses achados contrastam com a maioria dos resultados de estudos anteriores que investigaram simetria em sujeitos não-verbais, sobretudo em não-humanos (e.g., Barros et al., 1996; D’Amato et al., 1985; Devany et al., 1986; Dugdale \& Lowe, 2000; Gray, 1966; Hogan \& Zentall, 1977; Holmes, 1979; Lionello-DeNolf \& Urcuioli, 2002; Lipkens et al., 1988; Richards, 1988; Rodewald, 1974; Sidman et al., 1982) e sugerem 
que formação de classes de equivalência possa ser verificada em tais populações sob condições adequadas de treino e teste.

A presente proposta metodológica se diferencia das demais estratégias utilizadas para avaliar propriedades da equivalência por meio de testes reforçados (e.g. D'Amato, et al., 1985; Lionello-DeNolf \& Urcuioli, 2002) na medida em que as relações inéditas, treinadas como um controle experimental durante os testes, não são incompatíveis ou inconsistentes com a linha de base de relações condicionais previamente estabelecida. Tal estratégia tem sido aprimorada ao longo de pesquisas anteriores conduzidas com humanos verbalmente competentes (Velasco \& Tomanari, 2008; Velasco \& Tomanari, 2009) e traz avanços metodológicos significativos para o estudo da formação de classes de equivalências em animais não-humanos e humanos com desenvolvimento atípico.

Em primeiro lugar, a presente estratégia permite que relações consistentes e inéditas sejam concorrentemente reforçadas para um mesmo sujeito, evitando-se, assim, o emprego de delineamentos experimentais de grupo (e.g., Lionello-DeNolf \& Urcuioli, 2002; Urcuioli et al., 1989). Por não ser inconsistente com o treino da linha de base, o reforçamento das relações inéditas não deveria interferir nos desempenhos durante as tentativas em que são avaliadas as relações consistentes com a formação de classes de equivalência.

No campo aplicado, o uso de relações inéditas permite não só que repertórios complexos possam ser testados sob reforçamento diferencial, mas, sobretudo, que a condição de teste possa ser utilizada para adicionar novas relações entre estímulos ao repertório dos indivíduos em questão. Não sendo inconsistente com algo que o indivíduo tenha aprendido anteriormente, a condição de teste se configuraria, portanto, como uma condição adicional de ensino. Por exemplo, depois de ensinar um aluno a relacionar nomes em português a seus respectivos objetos (A-B), testes de simetria 
poderiam ser conduzidos durante os quais o reforçamento de relações entre objetos e seus nomes em português $(B-A)$ seria comparado ao treino de relações inéditas envolvendo os mesmos objetos e seus correspondentes nomes em inglês (B-C). Feito isso, relações transitivas entre nomes em português e nomes em inglês poderiam ser avaliadas $(\mathrm{A}-\mathrm{C})$ comparando-se o reforçamento dessas relações ao treino de outras relações inéditas envolvendo, por exemplo, nomes em português e nomes em espanhol (A-D) e assim por diante. Deste modo, as relações inéditas, empregadas como controle experimental em cada fase de teste passariam a integrar a própria linha de base de relações condicionais para que, posteriormente, novas relações emergentes pudessem ser avaliadas. Estratégia semelhante poderia ser utilizada para avaliar todas as propriedades definidoras de equivalência em um mesmo sujeito não-humano.

No presente estudo, conduzido com pombos, o treino das relações inéditas durante o primeiro teste de simetria teve ainda um propósito adicional. Enquanto que o treino das relações simétricas forneceu aos sujeitos uma experiência com modelos e comparações alterando papéis, o treino de relações inéditas serviu para estabelecer as discriminações sucessivas e simultâneas entre os modelos e comparações que iriam compor as relações simétricas do segundo teste, bem como para familiarizar os sujeitos com os estímulos em suas novas localizações. Tal procedimento, portanto, prescindiu do treino de relações de identidade que normalmente é utilizado para esse fim (Frank \& Wasserman, 2005; Sidman et al., 1992; Tomonaga, et al., 1991, Yamamoto \& Asano, 1995).

Recentemente, Urcuioli (2008) teorizou que o treino de identidade aliado ao procedimento de MTS sucessivo se configuraria como uma condição necessária à demonstração de simetria em pombos. De fato, até o presente momento as únicas demonstrações de simetria com essa população haviam sido obtidas empregando-se esses dois procedimentos em conjunto (Frank \& Wasserman, 2005; Urcuioli, 2008). No 
entanto, os resultados da presente pesquisa indicam que a demonstração de simetria em pombos é factível na ausência tanto do treino de identidade quanto do procedimento de MTS sucessivo. Para isso, entretanto, foi necessário fornecer aos sujeitos uma curta experiência com modelos e comparações alternando papéis (treino de exemplares de simetria), além de garantir que todos os pré-requisitos discriminativos necessários à demonstração de simetria fossem previamente estabelecidos.

Como foi discutido anteriormente, o treino de identidade realizado tanto por Frank e Wasserman (2005) quanto por Urcuioli (2008), além de apresentar cada estímulo como modelo e comparação, forneceu aos pombos uma experiência na qual responder a relações simétricas produzira uma mesma conseqüência programada (i.e., extinção). Se estiver correta a hipótese de que tal experiência tenha cumprido o mesmo papel de um treino de simetria, então, esses dois estudos, juntamente com o que compõe o presente trabalho, foram os únicos realizados com pombos que forneceram exemplares de relações simétricas e garantiram os controles discriminativos adequados.

Se por um lado esses resultados fortalecem a hipótese de que a linguagem não é um pré-requisito necessário à demonstração da formação de classes de equivalência, por outro, eles sugerem que uma história envolvendo relações simétricas, que também é fornecida ao longo da aquisição de competências lingüísticas, pode ser uma condição necessária à tal demonstração (ver também Schusterman \& Kastak, 1993; Yamamoto \& Asano, 1995).

Com o emprego de estratégias inovadoras no controle de variáveis que dificultam a emergência de relações condicionais em organismos não-verbais, o presente trabalho aponta um caminho promissor na consolidação de um modelo animal para o estudo do funcionamento simbólico e seus precursores, além de fornecer um conjunto de parâmetros para o desenvolvimento de procedimentos 
remediativos dirigidos a indivíduos que apresentam déficit no funcionamento lingüístico. 


\section{REFERÊNCIAS}

Antonitis, J.J. (1951). Response variability in the white rat during conditioning, extinction, and reconditioning. Journal of Experimental Psychology, 42, 273-281.

Azrin, N.H., Hutchinson, R.R., \& Hake, D.F. (1966). Extinction-induced aggression. Journal of the Experimental Analysis of Behavior, 9, 191-204.

Barnes-Holmes, Y., Barnes-Holmes, D., Roche, B., \& Smeets, P. M. (2001). Exemplar training and a derived transformation of function in accordance with symmetry: II. The Psychological Record, 51, 589-603.

Barros, R.S. (1998). Controle do comportamento por relações entre estímulos em Cebus apella. Tese de Doutorado, Universidade de São Paulo, São Paulo.

Barros, R.S., Galvão, O.F., \& Fontes, J.C. (1996). Um teste de simetria após treino de relações comdicionais de posição com macaco Ateles paniscus paniscus. Acta Comportamentalia, 4, 181-204.

Barros, R.S., Galvão, O.F., \& Mcllvane, W.J. (2002). Generalized identity matching-tosample in Cebus apella. The Psychological Record, 52, 441-460.

D’Amato, M.R., Salmon, D.P., Loukas, E., \& Tomie, A. (1985) Symmetry and transitivity of conditional relations in monkeys (Cebus apella) and Pigeons (Columbia livia). Journal of the Experimental Analysis of Behavior, 44, 35-47.

de Rose, J.C., Souza, D.G., Rossito, A.L., \& de Rose, T.M.S. (1989). Aquisição de leitura após história de fracasso escolar: equivalência de estímulos e generalização. Psicologia: Teoria e Pesquisa, 5, 325-346.

de Rose, J.C., Souza, D.G., \& Hanna, E.S. (1996). Teaching reading and spelling: Exclusion an stimulus equivalence. Journal of Applied Behavior Analysis, 29, 
451-469.

de Rose, J.C., \& Souza, D.G. (2006). Desenvolvendo um programa individualizado para o ensino de leitura. Acta Comportamentalia, 14, 77,98.

Devany, J.M., Hayes, S.C., \& Nelson, R.O. (1986). Equivalence class formation in language-able and language-disable children. Journal of the Experimental Analysis of Behavior, 46, 243-257.

Dube, W.V., \& Mcllvane, W.J. (1996). Some implications of a stimulus control topography analysis for emergent stimulus class. In T.R. Zental \& P.M. Smeets (Eds.), Stimulus class formation in humans and animals (pp. 197-218). Amsterdam: Elsevier.

Dube, W.V., Mcllvane, W.J., Callahan, T.D., \& Stoddard, L.T. (1993). The search for stimulus equivalence in nonverbal organisms. The Psychological Records, 43, 761-778.

Dugdale, N., \& Lowe, C.F. (1990). Naming and stimulus equivalence. In D.E. Blackman, \& H. Lejeune (Eds.), Behavior analysis in theory an practice (pp. 115138). Hove, UK: Erlbaum.

Dugdale, N., \& Lowe, C.F. (2000). Testing for symmetry in conditional discriminations of language-trained chimpanzees. Journal of the Experimental Analysis of Behavior, 73, 5-22.

Frank, A.J., \& Wasserman, E.A. (2005). Associative symmetry in the pigeon after successive matching-to-sample training. Journal of the Experimental Analysis of Behavior, 84, 147-165.

Galvão, O.F. (1993). Classes funcionais e equivalência de estímulos. Psicologia: Teoria e Pesquisa, 9, 547-554.

Galvão, O.F., Calcagno, S., \& Sidman, M. (1992). Testing for emergent performances 
in extinction. Experimental Analysis of Human Behavior Bulletin, 10, 18-20.

Gray, L. (1966). Backward association in pigeons. Psychonomic Science, 4, 333-334.

Hayes, S.C. (1989). Nonhumans have not yet shown stimulus equivalence. Journal of the Experimental Analysis of Behavior, 51, 385-392.

Hayes, S.C., Barnes-Holmes, D., \& Roche, B. (2001). Relational frame theory: A postSkinnerian account of language and cognition. New York: Plenum.

Herman, L.M., \& Gordon, J. A. (1974). Auditory delayed matching in bottlenose dolphin. Journal of the Experimental Analysis of Behavior, 21, 19-26.

Herman, L.M., Hovancik, P.R., Gory, J.D., \& Bradshaw, G.L. (1989). Generalization of visual matching by a bottlenose dolphin (Tursiops truncates): Evidence of invariance of cognitive performance with visual and auditory materials. Journal o Experimental Psychology: Animal Behavior Processes, 15, 124-136.

Hogan, D.E., \& Zentall, T.R. (1977). Backward associations in pigeon. American Journal of Psychology, 90, 3-15.

Holmes, P.W., (1979). Transfer of matching performance in pigeons. Journal of the Experimental Analysis of Behavior, 31, 103-114.

Horne, P.J., \& Lowe, C.F. (1996). On the origins of naming and other symbolic behavior. Journal of the Experimental Analysis of Behavior, 65, 185-242.

Iversen, I.H. (1997). Matching-to-sample performance in rats: A case of mistaken identity? Journal of the Experimental Analysis of Behavior, 68, 27-47.

Iversen, I.H., Sidman, M., \& Carrigan, P. (1986). Stimulus definition in conditional discriminations. Journal of Experimental Analysis of Behavior, 45, 297-304.

Kastak, D., \& Schusterman, R. J. (1994). Transfer of visual identity matching-to-sample in two California sea lions (Zalophus californianus). Animal Learning and 
Behaviour, 22, 427-435.

Keller, F.S., \& Schoenfeld, W.N. (1950). Principles of psychology: A systematic text in the science of behavior. New York: Appleton-Century-Crofts.

Kuno, H., Kitadate, T., \& Iwamoto, T. (1994). Formation of transitivity in conditional matching to sample by pigeons. Journal of the Experimental Analysis of Behavior, $62,399-408$

Lazar, R. (1977). Extending sequence-class membership with matching to sample. Journal of the Experimental Analysis of Behavior, 27, 381-392.

Lazar, R., Davis-Lang, D., \& Sanches, L. (1984). The formation of visual stimulus equivalence in children. Journal of the Experimental Analysis of Behavior, 41, 251-266.

Lerman, D.C., \& Iwata, B.A. (1996). Developing a technology for the use of operant extinction in clinical settings: An examination of basic and applied research. Journal of Applied Behavior Analysis, 29, 345-382.

Lionello-DeNolf, K.M. (2009). The search for symmetry: 25 years in review. Learning \& Behavior, 37, 188-203.

Lionello-DeNolf, K.M., \& Urcuioli, P.J., (1998). Control by sample location in pigeons' matching-to-sample. Journal of the Experimental Analysis of Behavior, 70, 235251.

Lionello-DeNolf, K.M., \& Urcuioli, P.J., (2000). Transfer of pigeons' matching-to-sample to novel sample location. Journal of the Experimental Analysis of Behavior, 73, $141-161$

Lionello-DeNolf, K.M., \& Urcuioli, P.J., (2002). Stimulus control topographies and test of symmetry in pigeons. Journal of the Experimental Analysis of Behavior, 78, 467-495. 
Lipkens, R., Kop, P.F.M., \& Matthijs, W. (1988). A test for symmetry and transitivity in the conditional discrimination performances of pigeons. Journal of the Experimental Analysis of Behavior, 49, 395-409.

Mackay, H.A., \& Sidman, M. (1984). Teaching new behavior via equivalence relations. In P.H. Brooks, R. Sperber, \& C. McCauley (Eds.), Learning and cognition in the mentally retarded (pp. 493-513). Hillsdale, NJ: Erlbaum.

Matos, M.A., Peres, W., Hübner, M.M., \& Malheiros, R.H. (1997). Oralização e cópia: efeitos sobre a aquisição de leitura generalizada recombinativa. Temas em Psicologia, 1, 47-64.

Medeiros, J.G., Antonakopoulu, A., Amorim, K., \& Righetto, A.C. (1997). O uso da discriminação condicional no ensino de leitura e escrita. Temas em Psicologia, 1, 23-32.

Melchiori, L.E., de Souza , D.G., \& de Rose, J.C. (2000). Reading, equivalence and recombinations of units: A replication with students diferent learning histories. Journal of Applied Behavior Analysis, 33, 97-100.

Oden, D.L., Thompson, R.K., \& Premack, D. (1988). Spontaneous transfer of matching in infant chimpanzees. Journal of the Experimental Psychology: Animal Behavior Processes, 14, 140-145.

Peña, T., Pitts, R.C., \& Galizio, M. (2006). Identity matching-to-sample with olfactory stimuli in rats. Journal of Experimental Analysis of Behavior, 85, 203-221.

Richards, R.R. (1988). The question of bidirectional associations in pigeons' learning of conditional discrimination tasks. Bulletin of the Psychonomic Society, 26, 577579.

Rodewald, H.K. (1974). Symbolic matching-to-sample by pigeons. Psychological Reports, 34, 987-990. 
Rico, V.V. (2009). Variáveis relevantes para a emergência de simetria em pombos (Columba livia). Projeto de Qualificação de Doutorado, Universidade de São Paulo, São Paulo.

Saunders, R.R., \& Green, G. (1999). A discriminations analyses o training-structure effects on stimulus equivalence outcomes. Journal of Experimental Analysis of Behavior, 72, 117-137.

Schusterman, R.J., \& Kastak, D. (1993). A California see lion (Zlophus californianus) is capable of forming equivalence relations. Psychological Record, 43, 823-839.

Sidman, M. (1971). Reading and auditory-visual equivalence. Journal of Speech and Hearing Research, 14, 5-13.

Sidman, M. (1990). Equivalence relations: Where do they come from? In D.E. Blackman, \& H. Lejeune (Eds.), Behavior analysis in theory and practice: Contributions and controversies (pp. 93-114). Hove, UK: Erlbaum.

Sidman, M. (1992). Adventitious control by the location of comparison stimuli in conditional discriminations. Journal of the Experimental Analysis of Behavior, 58, 143-182.

Sidman, M. (1994). Equivalence relations and behavior: A research story. Boston: Authors Cooperative Pub.

Sidman, M. (2000). Equivalence relations and the reinforcement contingency. Journal of the Experimental Analysis of Behavior, 74, 127-146.

Sidman, M., \& Cresson, O.Jr. (1973). Reading and crossmodal transfer of stimulus equivalence in severe retardation. American Journal of Mental Deficiency, 77, 515-523.

Sidman, M., Kirk, B., \& Willson-Morris, M. (1985). Six-member stimulus classes generated by conditional-discrimination procedure. Journal of the Experimental 
Analysis of Behavior, 43, 21-42.

Sidman, M., Rauzin, R., Lazar, R., Cunninghan, S., Tailby, W., \& Carrigan, P. (1982). A search for symmetry in the conditional discrimination of rhesus monkeys, baboons and children. Journal of the Experimental Analysis of Behavior, 37, 2344.

Sidman, M., \& Tailby, W. (1982). Conditional discrimination vs. matching to sample: An expansion of the testing paradigm. Journal of the Experimental Analysis of Behavior, 53, 47-63.

Sidman, M., Willson-Morris, M., \& Kirk, B. (1986). Matching-to-sample procedures and the development of equivalence relations: The role of naming. Analysis and Intervention in Developmental Disabilities, 6, 1-19.

Silverman, K., Anderson, S.R., Marshall, A.M., \& Baer, D.M. (1986). Establishing and generalizing audience control of new language repertoires. Analyses and Intervention in Developmental disabilities, 6, 21-40.

Skinner, B.F. (1938). The behavior of organisms. New York: Appleton-Century-Crofts.

Spradlin, J.E., Cotter, V.W., \& Baxley, N. (1973). Establishing a conditional discrimination without direct training: A study of transfer with retarded adolescents. American Journal of Mental Deficiency, 77, 556-566.

Tomonaga, M., Matsuzawa, T., Fujita, K., \& Yamamoto, J. (1991). Emergence of symmetry in a visual conditional discrimination by chimpanzees (Pan troglodytes). Psychological Reports, 68, 51-60.

Urcuioli, P.J. (2008). Associative symmetry, antisymmetry, and a theory of pigeons' equivalence-class formation. Journal of the Experimental Analysis of Behavior, 90, 257-282.

Urcuioli, P.J., Zentall, T.R., Jackson-Smith, P., \& Steirn, J.N. (1989). Evidence for 
common coding in many-to-one matching: Retention, intertrial interference, and transfer. Journal of Experimental Psychology: Animal Behavior Processes, 15, 264-373.

Velasco. S.M., \& Tomanari, G.Y. (2008, September). The effects of symmetry training on the acquisition of conditional discriminations. Paper presented at the Fourth Conference of the European Association for Behaviour Analysis, Madrid.

Velasco. S.M., \& Tomanari, G.Y. (2009). Efeitos do treino de discriminações condicionais sobre a aquisição de relações simétricas e transitivas. Acta Comportamentalia, 17, 1, 97-116.

Villas-Bôas, A.V., Murayama, V.K., \& Tomanari, G.Y. (2005). Ressurgência: conceitos e métodos que podem (ou não) contribuir para a Análise do Comportamento. In H. Guilhardi \& N.C. de Aguirre (Eds.). Sobre comportamento e cognição (pp. 1828). Sant André: ESEtec Editores Associados.

Wilson, K.G., \& Hayes, S.C. (1996). Resurgence of derived stimulus relations. Journal of the Experimental Analysis of Behavior, 66, 267-281.

Yamamoto, J., \& Asano, T. (1995). Stimulus equivalence in a chimpanzee (Pan troglodytes). The Psychological Record, 45, 3-21.

Zentall, T.R., Edwards, C.A., Moore, B.S., \& Hogan, D.E. (1981). Identity: the bases for both matching and oddity learning in pigeons. Journal of the Experimental Psychology: Animal Behavior Processes, 7, 70-86.

Zentall, T.R., \& Hogan, D.E. (1976). Pigeons can learn identity or difference, or both. Science, 191, 408-409. 